\title{
Distribution of highly arsenic and fluoride contaminated groundwater from east Punjab, Pakistan, and the controlling role of anthropogenic pollutants in the natural hydrological cycle
}

\author{
Abida Faroogi, ${ }^{1}$ Harue Masuda,,${ }^{1}$ Minoru Kusakabe, ${ }^{2 * *}$ Muhammad Naseem ${ }^{3}$ and Nousheen Firdous ${ }^{3}$ \\ ${ }^{1}$ Department of Geosciences, Osaka City University, 3-3-138, Sugimoto, Sumiyoshi-ku, Osaka 558-8585, Japan \\ ${ }^{2}$ Institute for the Study of the Earth's Interior, Okayama University, Japan \\ ${ }^{3}$ Geosciences Laboratory, Geological Survey of Pakistan, Chak Shehzad, Islamabad, Pakistan
}

(Received July 13, 2006; Accepted November 26, 2006)

\begin{abstract}
This paper reports the extended study from a previously-described study on As and F contaminated groundwater from a small village, Kalalanwala, in east Punjab, Pakistan (Farooqi et al., 2007). Of the 147 groundwater samples investigated, $91 \%$ exceeded the WHO standard $(10 \mu \mathrm{g} / \mathrm{L})$ for As and $75 \%$ exceeded the WHO standard $(1.5 \mathrm{mg} / \mathrm{L})$ for $\mathrm{F}^{-}$. The highly contaminated As $(\max .2400 \mu \mathrm{g} / \mathrm{L})$ and $\mathrm{F}^{-}(\max .22 .8 \mathrm{mg} / \mathrm{L})$ groundwaters were found from shallow depths down to $30 \mathrm{~m}$ from the surface. The contaminated groundwaters are characterized by high $\mathrm{pH}$ (max. 8.8), alkalinity $\left(\mathrm{HCO}_{3}{ }^{-}\right.$up to 1281 $\mathrm{mg} / \mathrm{L}), \mathrm{SO}_{4}{ }^{2-}(\max .960 \mathrm{mg} / \mathrm{L}), \mathrm{Na}^{+}(\max .1058 \mathrm{mg} / \mathrm{L})$ and maximum electric conductivity $>4.6 \mathrm{mS} / \mathrm{cm}$.

Fluoride concentrations showed positive correlations with those of $\mathrm{Na}^{+}$and $\mathrm{HCO}_{3}{ }^{-}$and negative ones with $\mathrm{Ca}^{2+}$ and $\mathrm{Mg}^{2+}$. The alkaline waters were saturated with calcite in spite of the low $\mathrm{Ca}^{2+}$ concentrations. Fluoride concentration is governed by fluorite solubility. Speciation analysis showed As is mostly in the form of As ${ }^{\mathrm{V}}$. There was a positive correlation between As and $\mathrm{pH}$, while there is no relationship between As vs. Fe and $\mathrm{F}^{-}$. Thus, the fluoride and As contamination occurred in the oxidizing and alkaline conditions of the groundwater. However, $\mathrm{F}^{-}$and As are derived from two or more sources. Suspected contaminant sources in the study area contained considerable amounts of $\mathrm{F}^{-}$and As; fertilizers (DAP, $n=5$ ) contained leachable $\mathrm{F}^{-}$ranging from $53-255 \mathrm{mg} / \mathrm{kg}$, and As $5-10 \mathrm{mg} / \mathrm{kg}$, and coals $(n=8)$ contained $\mathrm{F}^{-}$ ranging from $5-20 \mathrm{mg} / \mathrm{kg}$.

Sulfur isotopic ratios indicated that the high $\mathrm{SO}_{4}{ }^{2-}$ in groundwater $(3.2-7.0 \%$, CDT) is mainly derived from coal combusted atmospheric pollutants, fertilizers and household wastes. Nitrogen isotope data (8-30\%o, Air) showed that $\mathrm{NO}_{3}{ }^{-}-\mathrm{N}$ is attributed to animal waste distributed in the study area. The major chemical characteristics of the groundwaters are related with anthropogenic activities on the ground surface. The resultant major chemistry, especially highly alkaline and low $\mathrm{Ca}^{2+}$ and $\mathrm{Mg}^{2+}$ concentrations, must promote the high concentrations of $\mathrm{F}^{-}$and As in the studied groundwaters.
\end{abstract}

Keywords: environmental pollution, phosphorus, semiarid climate, Indus Basin nitrogen and sulfur isotopes

\section{INTRODUCTION}

Natural and anthropogenic pollutants threaten the quality of life through the environmental pollution. From the point of view of groundwater contamination, As and $\mathrm{F}^{-}$ have received the most attention due to their toxicity (e.g., Smedley et al., 2002). The release of soluble As species into groundwater is a serious problem in many areas of the world (e.g., Varsanyi et al., 1991; Lepkowski, 1998; Welch et al., 2000; Tian et al., 2001; Bhattacharya et al., 2004; Nickson et al., 2005). The World Health Organiza-

*Corresponding author (e-mail: harue@ sci.osaka-cu.ac.jp)
**Present address: Korea Polar Research Institute, KORDI, Songdo
Techno Park 7-50, Songdo-dong, Yeonsu-gu, Incheon 406-840, Korea.

Copyright @ 2007 by The Geochemical Society of Japan. tion (WHO) guideline of As concentration in drinking water was reduced from $50 \mu \mathrm{g} / \mathrm{L}$ to $10 \mu \mathrm{g} / \mathrm{L}$ in 1993 (WHO, 1993). According to the WHO recommendation many developed countries changed the maximum admissible concentrations to $10 \mu \mathrm{g} / \mathrm{L}$, however the developing countries, where arsenicosis is more widespread, are still using the previous guideline value $(50 \mu \mathrm{g} / \mathrm{L})$ due to the lack of facilities to analyze smaller concentrations precisely (Nickson et al., 2005).

High $\mathrm{F}^{-}$groundwater causes fluorosis in several regions of the world; East Africa (Nanyaro et al., 1984), India (Rao et al., 1993), and Inner Mongolia in China (Wang et al., 1999). The drinking water limit (DWL) for $\mathrm{F}^{-}$is $1.5 \mathrm{mg} / \mathrm{L}$ (WHO, 1994). Fluoride in drinking water has a narrow optimum concentration range in relation to human health. It prevents dental caries in the range of $0.7-1.2 \mathrm{mg} / \mathrm{L}$, but is responsible for dental and skeletal 


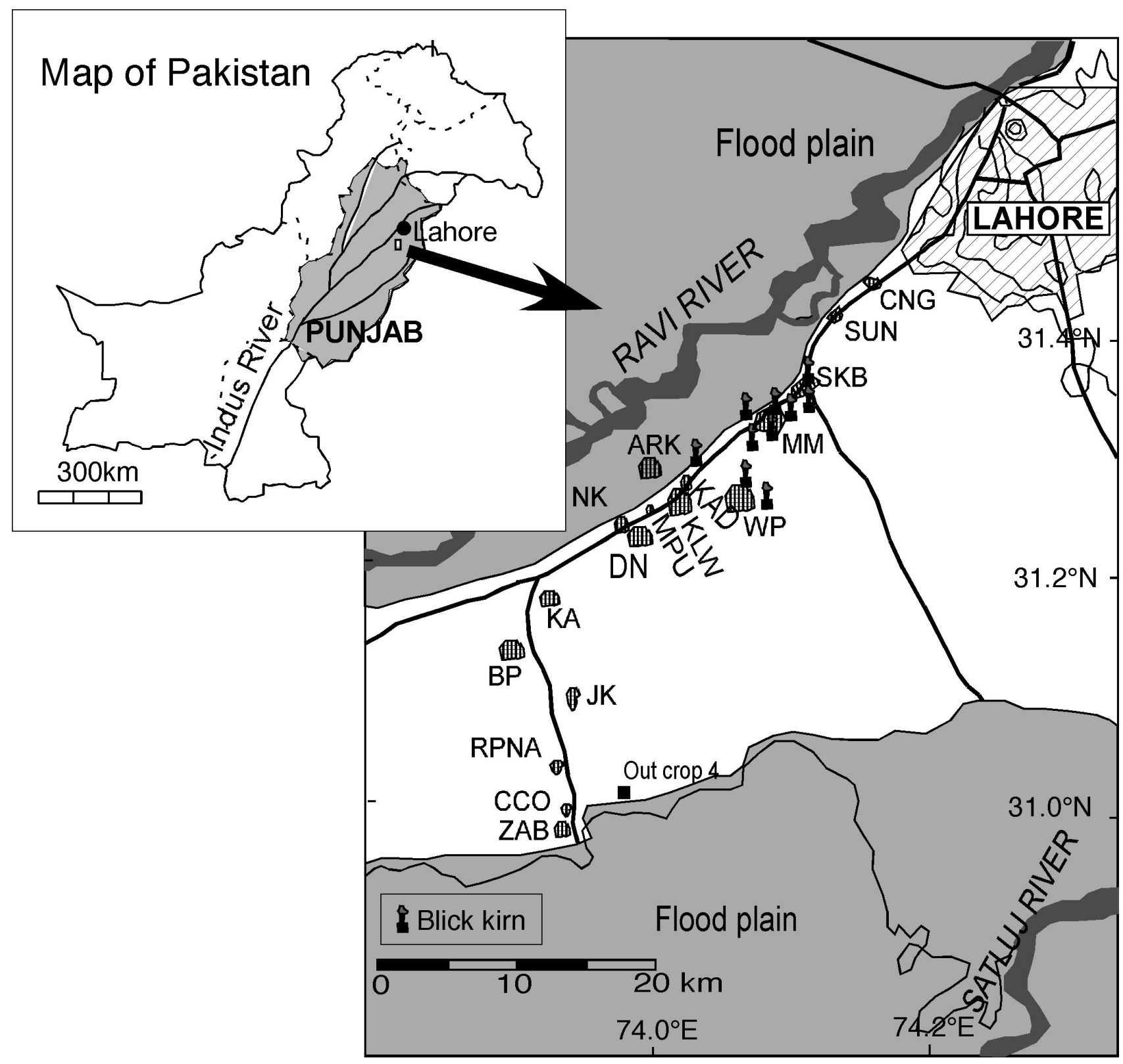

Fig. 1. Index map showing the Punjab, study area, and location of brick kilns. Flood plain is shaded. The abbreviations for description of villages are the same as those in Table 1. The hatched area with abbreviations is the residential area.

fluorosis, if it is higher than $1.5 \mathrm{mg} / \mathrm{L}$ (CDCP, 1999).

The Pakistan Council for Research and Water Resources (PCRWR) and UNICEF have undertaken the assessment of drinking water quality since 1999 following the As crisis in Bangladesh and other neighboring countries. Consequently, the presence of As contaminated groundwaters $(10-200 \mu \mathrm{g} / \mathrm{L})$ has been recognized in many areas of Pakistan (www.pcrwr.gov.pk/Arsenic).

We reported As and $\mathrm{F}^{-}$contamination of groundwater in a small village Kalalanwala, $30-35 \mathrm{~km}$ south of La- hore, where $>400$ residents, mostly less than 15 years old, were diagnosed with bone deformity disease and molted teeth (Farooqi et al., 2007). The maximum concentration of As was $1,900 \mu \mathrm{g} / \mathrm{L}$ and that of $\mathrm{F}^{-} 21.1 \mathrm{mg} / \mathrm{L}$. In addition to the high As and $\mathrm{F}^{-}$, the groundwater contained high concentrations sulfate and was highly alkaline. Although As and $\mathrm{F}^{-}$contaminated groundwater is distributed throughout the whole country, the situation of our reported area is more serious than in other areas where the maximum concentration of total As reported by 
PCRWR was $200 \mu \mathrm{g} / \mathrm{L}$, and that of $\mathrm{F}^{-}$was $<2.0 \mathrm{mg} / \mathrm{L}$ (www.pcrwr.gov.pk/Arsenic), and As in groundwater from Muzaffargarh area (south western edge of the Punjab) was $960 \mu \mathrm{g} / \mathrm{L}$ (Nickson et al., 2005).

On the basis of the previous report (Farooqi et al., 2007), this study has been extended to 17 villages surrounding Kalalanwala, in order to reveal the extent and degree of groundwater pollution and to estimate the principal controlling geochemical factors concerned with the As and $\mathrm{F}^{-}$pollution. This is based on the water chemistry including $\mathrm{H}, \mathrm{O}, \mathrm{S}$ and $\mathrm{N}$ isotopic ratios.

\section{Geography, Geology ANd Climate OF THE STUdy AREA}

The Punjab province, Pakistan, is located between 24 $37^{\circ} \mathrm{N}$ and $62-75^{\circ} \mathrm{E}$ within an alluvial plain of the southflowing Indus River and its five major tributaries. The districts of Lahore and Kasur are located in the central Pakistan at the eastern edge of the Punjab Province occupying an area of 3,995 and $1,772 \mathrm{~km}^{2}$ and total population of 2.31 and 6.31 million, respectively. The present study area covers $1 / 5$ th of the Kasur and 1/6th of the Lahore districts. The area is located along the eastern bank of River Ravi (Fig. 1) and includes 17 villages between Chung, 15-20 km south from main Lahore and Zahirabad near to the district Chunian (Fig. 1). For daily water use, including drinking water, most of the residents use groundwater extracted from tube wells drilled up to $30 \mathrm{~m}$ in depth from the ground surface within individual dwellings.

Hydrology, hydrogeology, and aquifer sediments of the Punjab were first described in detail by Greenman et al. (1967); the Punjab Province is in an alluvial plain comprising $>350 \mathrm{~m}$ thick Holocene and Pleistocene sediments transported by the Ravi and Satluj rivers. The sediments are mostly sand, containing high percentage of fine to very fine sand and silt and low organic matter content. The area is mainly recharged by the Ravi and Satluj rivers during monsoon season; however, the recharge from the rivers has diminished since canal irrigation started in the 17 th century.

The Punjab province has a semiarid and subtropical continental climate characterized by sultry summers and cold winters. The mean annual maximum temperature recorded from May to June is $41^{\circ} \mathrm{C}$ and the mean annual minimum temperature from December to January is $4^{\circ} \mathrm{C}$ (Ali et al., 1968).

Quaternary sediments, mainly of alluvial and deltaic origin, occur over large parts of the Indus Plain of Pakistan, predominantly in Punjab Province, (WAPDAEUAD, 1989). The sediments there have some similarities to those of the As affected aquifers in Bangladesh and West Bengal, being Quaternary alluvial-deltaic sediments derived from Himalayan source rocks. However, the Indus basin is climatically arid, and comprises older Pleistocene deposits including eolian sediments and is dominated by aerobic conditions of unconfined groundwater aquifers (Mahmood et al., 1998; Tasneem, 1999; Cook, 1987).

\section{SAMPLING AND ANALYSIS}

The wells are installed into three different depths in the $c a .800 \mathrm{~km}^{2}$ study area, and 147 groundwater samples were collected from those different depths: these comprise 123 samples from the shallow hand tube wells installed at 27-30 $\mathrm{m}$ in depth, 14 from $40-80 \mathrm{~m}$ in depth and 8 from deep wells $80-200 \mathrm{~m}$ in depth. In addition, two samples were collected from a canal drawn from Chenab River which originates from Indian Territory (Fig. 1).

Water temperature, $\mathrm{pH}$, ORP, electric conductivity (EC) and alkalinity (quoted as $\mathrm{HCO}_{3}{ }^{-}$) were measured in situ. The ORP values were transformed to standard hydrogen electrode (SHE) readings (Eh) because the Ag/ $\mathrm{AgCl}$ reference electrode had a difference of $+200 \mathrm{mV}$ with respect to SHE (Szogi et al., 2004). At each site, water samples were collected for the laboratory analysis. After filtering the sample water using a $0.45 \mu \mathrm{m}$ membrane filter, the water was transferred to two polyethylene bottles; one was acidified to $0.06 \mathrm{~N} \mathrm{HCl}$ for the quantitative analysis of cations $\left(\mathrm{Na}^{+}, \mathrm{K}^{+}, \mathrm{Ca}^{2+}\right.$, and $\left.\mathrm{Mg}^{2+}\right)$, total As, and sulfur isotopes. The other aliquot was not acidified and used for anion analysis $\left(\mathrm{Br}^{-}, \mathrm{Cl}^{-}, \mathrm{F}^{-}, \mathrm{PO}_{4}{ }^{3-}\right.$, and $\mathrm{SO}_{4}{ }^{2-}$ ) and hydrogen and oxygen isotope analyses. For $\mathrm{As}^{\mathrm{III}}$ and nitrogen isotope analysis $50 \mathrm{~mL}$ of water acidified to be $0.09 \mathrm{~N} \mathrm{H}_{2} \mathrm{SO}_{4}$ solution was tightly sealed in a glass bottle. Sodium and $\mathrm{K}^{+}$were determined by atomic absorption spectrometry (SAS 7500, Seiko). Calcium and $\mathrm{Mg}^{2+}$ were analyzed by volumetric titration with ethylenediaminetetraacetic acid (EDTA $0.05 \mathrm{~N}$ ) with an analytical error $< \pm 2 \%$. Chloride, $\mathrm{Br}^{-}, \mathrm{PO}_{4}{ }^{3-}, \mathrm{SO}_{4}{ }^{2-}$ and $\mathrm{F}^{-}$ were determined by Ion chromatograph (DX-120, Dionex) with a precision $< \pm 2 \%$, estimated using duplicated standard solutions. Silica and Fe were determined with ICPAES.

Water soluble fluoride in fertilizers was extracted to determine the concentration. Five grams of fertilizer sample and $25 \mathrm{~mL}$ distilled water were placed in polyethylene bottles, shaken for 0.5 hour on a shaker, centrifuged and the resultant water was used for the analysis by ion selective electrode (Orion) and ion meter (Metro Ohm). Total $\mathrm{F}^{-}$in coal samples was analyzed by ion chromatography after the coal was alkali fused and dissolved in water (Shimizu et al., 2006; Crossley, 1944). The reproducibility of analytical data was $<10 \%$ for the duplicated samples. For total As in coal samples, acid digestion was used 
Table 1. Concentration ranges of major anions, cations and isotopic ratios of groundwater in east Punjab, Pakistan

\begin{tabular}{|c|c|c|c|c|c|c|c|c|c|c|c|c|c|}
\hline \multirow[t]{2}{*}{ Locality } & \multirow[t]{2}{*}{ Abbr. } & \multicolumn{3}{|c|}{$\mathrm{HCO}_{3}^{-}[\mathrm{mg} / \mathrm{L}]$} & \multicolumn{3}{|c|}{$\mathrm{Cl}^{-}[\mathrm{mg} / \mathrm{L}]$} & \multicolumn{3}{|c|}{$\mathrm{SO}_{4}{ }^{2-}[\mathrm{mg} / \mathrm{L}]$} & \multicolumn{3}{|c|}{$\mathrm{NO}_{3}^{-}-\mathrm{N}[\mathrm{mg} / \mathrm{L}]$} \\
\hline & & Min & $\operatorname{Max}$ & Mean & Min & $\operatorname{Max}$ & Mean & Min & $\operatorname{Max}$ & Mean & Min & Max & Mean \\
\hline Chung & $\mathrm{CNG}$ & 550 & 980 & 600 & 51 & 131 & 74 & 120 & 192 & 125 & bdl & 7.00 & 2.33 \\
\hline Sundar & SUN & 732 & 1040 & 884 & 21 & 180 & 117 & 120 & 432 & 303 & bdl & 4.48 & 2.60 \\
\hline Shamkey & SKB & 366 & 854 & 616 & 5 & 96 & 26 & 35 & 290 & 77 & bdl & 4.20 & 1.22 \\
\hline Manga Mandi & MM & 201 & 610 & 430 & 11 & 262 & 79 & 14 & 440 & 250 & bdl & 46.0 & 6.50 \\
\hline Waran Piranwala & WP & 440 & 616 & 520 & 13 & 129 & 71 & 72 & 341 & 200 & bdl & 5.90 & 1.20 \\
\hline Kot Asad Ullah & KAD & 165 & 1037 & 537 & 5 & 241 & 212 & 30 & 672 & 461 & bdl & 2.00 & 0.3 \\
\hline Kalalanwala & KLW & 244 & 1280 & 836 & 16 & 344 & 106 & 48 & 912 & 312 & bdl & 10.64 & 1.26 \\
\hline Muffat Pura & MPU & 610 & 1160 & 915 & 62 & 213 & 138 & 211 & 960 & 581 & bdl & bdl & bdl \\
\hline Araiyan Da Khu & ARK & 147 & 370 & 244 & 4 & 71 & 25 & 24 & 144 & 77 & bdl & 7.84 & 1.30 \\
\hline Deena Nath & DN & 610 & 915 & 702 & 12 & 140 & 83 & 96 & 240 & 144 & bdl & 19.00 & 4.60 \\
\hline Nathe Khalsa & NK & 490 & 915 & 732 & 14 & 70 & 46 & 96 & 240 & 163 & bdl & 0.70 & 0.40 \\
\hline Kot Ashraf & KA & 610 & 671 & 630 & 54 & 121 & 83 & 192 & 290 & 231 & 0.14 & 11.50 & 0.90 \\
\hline Bahi Pheru & $\mathrm{BP}$ & 213 & 550 & 427 & 41 & 52 & 46 & 67 & 170 & 127 & bdl & 2.52 & 1.30 \\
\hline Jamber Klan & JK & 980 & 980 & 980 & 224 & 390 & 320 & 580 & 640 & 600 & 10.90 & 10.50 & 9.80 \\
\hline Rehman Pura & RPNA & 494 & 494 & 494 & 107 & 144 & 125 & 355 & 500 & 432 & 2.60 & 10.00 & 6.20 \\
\hline Cantt Colony & $\mathrm{CCO}$ & 370 & 430 & 400 & 10 & 15 & 12 & 39 & 72 & 54 & bdl & bdl & bdl \\
\hline Zaheer Abad & ZAB & 480 & 793 & 610 & 213 & 415 & 304 & 480 & 960 & 672 & 7.00 & 14.00 & 9.52 \\
\hline
\end{tabular}

\begin{tabular}{|c|c|c|c|c|c|c|c|c|c|c|c|c|c|}
\hline \multirow[t]{2}{*}{ Locality } & \multirow[t]{2}{*}{ Abbr. } & \multicolumn{3}{|c|}{$\mathrm{Ca}^{2+}[\mathrm{mg} / \mathrm{L}]$} & \multicolumn{3}{|c|}{$\mathrm{Mg}^{2+}[\mathrm{mg} / \mathrm{L}]$} & \multicolumn{3}{|c|}{$\mathrm{Na}^{+}[\mathrm{mg} / \mathrm{L}]$} & \multicolumn{3}{|c|}{$\mathrm{K}^{+}[\mathrm{mg} / \mathrm{L}]$} \\
\hline & & Min & $\operatorname{Max}$ & Mean & Min & $\operatorname{Max}$ & Mean & Min & Max & Mean & Min & $\operatorname{Max}$ & Mean \\
\hline Chung & $\mathrm{CNG}$ & 28 & 48 & 36 & 5 & 18 & 11 & 46 & 460 & 276 & 3.90 & 8.97 & 5.70 \\
\hline Sundar & SUN & 8 & 51 & 35 & 4 & 35 & 15 & 370 & 575 & 480 & 3.12 & 11.7 & 7.50 \\
\hline Shamkey & SKB & 2 & 71 & 20 & 2 & 46 & 13 & 69 & 368 & 238 & 1.95 & 9.75 & 7.80 \\
\hline Manga Mandi & MM & 5 & 93 & 54 & 2 & 61 & 27 & 46 & 460 & 210 & 2.73 & 39.00 & 12.00 \\
\hline Waran Piranwala & WP & 4 & 54 & 23 & 2 & 16 & 10 & 115 & 437 & 315 & 2.73 & 7.80 & 5.12 \\
\hline Kot Asad Ullah & KAD & 13 & 80 & 34 & 8 & 40 & 17 & 28 & 782 & 470 & 6.24 & 9.00 & 8.20 \\
\hline Kalalanwala & KLW & 5 & 75 & 21 & 2 & 36 & 12 & 207 & 1060 & 483 & 3.90 & 12.10 & 7.05 \\
\hline Muffat Pura & MPU & 34 & 57 & 47 & 11 & 23 & 17 & 300 & 805 & 600 & 6.24 & 11.70 & 9.08 \\
\hline Araiyan Da Khu & ARK & 19 & 140 & 80 & 6 & 26 & 13 & 16 & 51 & 28 & 3.90 & 27.30 & 11.00 \\
\hline Deena Nath & $\mathrm{DN}$ & 27 & 64 & 50 & 2 & 28 & 15 & 276 & 506 & 334 & 7.80 & 11.70 & 9.01 \\
\hline Nathe Khalsa & NK & 11 & 66 & 40 & 6 & 35 & 20 & 230 & 391 & 300 & 7.80 & 15.60 & 11.04 \\
\hline Kot Ashraf & KA & 6 & 47 & 30 & 3 & 28 & 17 & 253 & 370 & 330 & 3.90 & 11.70 & 9.00 \\
\hline Bahi Pheru & $\mathrm{BP}$ & 10 & 39 & 24 & 4 & 17 & 10 & 69 & 300 & 215 & 4.29 & 5.07 & 5.00 \\
\hline Jamber Klan & $\mathrm{JK}$ & 12 & 54 & 8 & 11 & 45 & 7 & 851 & 874 & 863 & 12.87 & 46.80 & 30.00 \\
\hline Rehman Pura & RPNA & 4 & 23 & 53 & 5 & 14 & 40 & 240 & 44 & 345 & 11.70 & 23.40 & 18.00 \\
\hline Cantt Colony & $\mathrm{CCO}$ & 60 & 66 & 63 & 31 & 47 & 24 & 12 & 19 & 16 & 19.50 & 27.30 & 24.00 \\
\hline Zaheer Abad & $\mathrm{ZAB}$ & 6 & 15 & 12 & 2 & 13 & 9 & 575 & 900 & 713 & 9.75 & 19.50 & 15.00 \\
\hline
\end{tabular}

(Aruscavage, 1977). A $0.1 \mathrm{~g}$ sample was taken into 125 mL Erlenmeyer flask; $20 \mathrm{~mL} \mathrm{HNO}_{3}$ and $2 \mathrm{~mL} \mathrm{H}_{2} \mathrm{SO}_{4}$ were added and left overnight. $3 \mathrm{~mL}$ of $\mathrm{HClO}_{4}$ was added into the flask, which was then heated at $175^{\circ} \mathrm{C}$ with a refluxer. After heating for $30 \mathrm{~min}$., the refluxer was removed and the flask was heated continually till dense fumes came out. Finally, the flask was cooled down and $25 \mathrm{~mL} 6 \mathrm{~N}$ $\mathrm{HCl}$ was added. The obtained sample solution was analyzed by hydride generation atomic absorption spectrometry (HGAAS, SAS 7500, Seiko Instruments).

For total As analysis, $2 \mathrm{~mL}$ of $12 \mathrm{M} \mathrm{HCl}$ was added to $15 \mathrm{~mL}$ of sample water together with $0.25 \mathrm{~mL}$ of a solution containing $10 \% \mathrm{KI}$ and $10 \%$ ascorbic acid. Hydride generation atomic absorption spectrometry (HGAAS,
SAS 7500, Seiko Instruments) was employed to measure the total As produced as the gaseous form $\left(\mathrm{AsH}_{3}\right)$ by reduction using sodium borohydride as reductant. Reproducibility of the analytical data was within $5 \%$, and the analytical error estimated to be $<10 \%$, based on the analytical results of standard stock solutions independently prepared from the commercially distributed standard solution using a standard calibration line. The lower limit of quantification of As was $1 \mathrm{ppb}$.

Arsenite ( $\mathrm{As}^{\mathrm{III}}$ ) concentrations were determined by the Voltammetry introduced by Holak (1980). The Voltammetry applied for natural waters has an advantage to reduce interference by dissolved salts. The lower detection limit of arsenite was $5 \mathrm{ppb}$, and the relative stand- 
Table 1. (continued)

\begin{tabular}{|c|c|c|c|c|c|c|c|c|c|c|c|c|c|}
\hline \multirow[t]{2}{*}{ Locality } & \multirow[t]{2}{*}{ Abbr. } & \multicolumn{3}{|c|}{$\mathrm{EC}[\mathrm{mS} / \mathrm{cm}]$} & \multicolumn{3}{|c|}{$\mathrm{Eh}[\mathrm{mV}]$} & \multicolumn{3}{|c|}{$\mathrm{pH}$} & \multicolumn{3}{|c|}{$\mathrm{SiO}_{2}[\mathrm{mg} / \mathrm{L}]$} \\
\hline & & Min & $\operatorname{Max}$ & Mean & Min & $\operatorname{Max}$ & Mean & Min & $\operatorname{Max}$ & Mean & Min & $\operatorname{Max}$ & Mean \\
\hline Chung & $\mathrm{CNG}$ & 0.38 & 1.95 & 1.24 & 257 & 320 & 298 & 7.3 & 8.3 & 7.8 & 12 & 27 & 23 \\
\hline Sundar & SUN & 1.30 & 2.60 & 2.10 & 273 & 363 & 328 & 7.2 & 8.1 & 7.8 & 21 & 25 & 23 \\
\hline Shamkey & SKB & 0.70 & 1.70 & 1.12 & 218 & 358 & 312 & 7.2 & 8.8 & 8.0 & 15 & 29 & 23 \\
\hline Manga Mandi & $\mathrm{MM}$ & 0.55 & 1.90 & 1.20 & 265 & 362 & 332 & 7.2 & 8.7 & 8.2 & 15 & 34 & 27 \\
\hline Waran Piranwala & WP & 0.82 & 2.00 & 1.61 & 291 & 360 & 313 & 7.8 & 8.6 & 8.0 & 12 & 27 & 21 \\
\hline Kot Asad Ullah & KAD & 0.34 & 3.70 & 2.20 & 222 & 316 & 287 & 7.6 & 8.3 & 7.7 & 7 & 20 & 14 \\
\hline Kalalanwala & KLW & 0.45 & 4.60 & 2.19 & 225 & 343 & 276 & 7.6 & 8.7 & 8.1 & 16 & 27 & 22 \\
\hline Muffat Pura & MPU & 1.40 & 4.10 & 2.90 & 315 & 324 & 323 & 7.7 & 8.0 & 7.5 & 18 & 26 & 23 \\
\hline Araiyan Da Khu & ARK & 0.20 & 1.00 & 0.56 & 273 & 385 & 306 & 7.2 & 7.6 & 7.5 & 10 & 20 & 16 \\
\hline Deena Nath & $\mathrm{DN}$ & 1.10 & 2.10 & 1.50 & 220 & 775 & 361 & 7.3 & 8.0 & 7.9 & 15 & 37 & 26 \\
\hline Nathe Khalsa & NK & 1.24 & 1.70 & 1.40 & 276 & 346 & 314 & 7.3 & 7.9 & 7.7 & 12 & 32 & 24 \\
\hline Kot Ashraf & $\mathrm{KA}$ & 1.20 & 1.38 & 1.50 & 288 & 320 & 304 & 8.2 & 8.6 & 8.1 & 19 & 27 & 23 \\
\hline Bahi Pheru & $\mathrm{BP}$ & 0.64 & 1.50 & 1.11 & 310 & 337 & 325 & 7.5 & 8.1 & 8.0 & 12 & 29 & 21 \\
\hline Jamber Klan & JK & 3.40 & 3.60 & 3.50 & 322 & 329 & 324 & 8.1 & 8.3 & 8.0 & 18 & 21 & 20 \\
\hline Rehman Pura & RPNA & 1.82 & 2.10 & 1.90 & 258 & 264 & 261 & 7.5 & 7.8 & 7.6 & 19 & 22 & 21 \\
\hline Cantt Colony & $\mathrm{CCO}$ & 0.50 & 0.70 & 0.60 & 243 & 258 & 254 & 7.2 & 7.3 & 7.6 & 25 & 29 & 27 \\
\hline Zaheer Abad & $\mathrm{ZAB}$ & 2.20 & 4.40 & 3.20 & 218 & 343 & 283 & 7.4 & 8.5 & 8.2 & 15 & 30 & 25 \\
\hline
\end{tabular}

\begin{tabular}{|c|c|c|c|c|c|c|c|c|c|c|c|c|c|}
\hline \multirow[t]{2}{*}{ Locality } & \multirow[t]{2}{*}{ Abbr. } & \multicolumn{3}{|c|}{$\mathrm{Fe}[\mathrm{mg} / \mathrm{L}]$} & \multicolumn{3}{|c|}{$\delta^{18} \mathrm{O}[\% o]$} & \multicolumn{3}{|c|}{$\delta \mathrm{D}[\% 0]$} & \multicolumn{3}{|c|}{$\delta^{34} \mathrm{~S}[\% 0]$} \\
\hline & & Min & Max & Mean & Min & Max & Mean & Min & Max & Mean & Min & $\operatorname{Max}$ & Mean \\
\hline Chung & $\mathrm{CNG}$ & bdl & 0.17 & 0.05 & -8.37 & -7.5 & -8.19 & -53.8 & -46.9 & -52.4 & 5.1 & 5.4 & 5.3 \\
\hline Sundar & SUN & bdl & 0.10 & 0.03 & -8.50 & -7.30 & -7.68 & -53.25 & -45.9 & -53.18 & 5.7 & 5.7 & 5.7 \\
\hline Shamkey & SKB & bdl & 0.24 & 0.09 & -9.30 & 7.79 & -8.66 & -61.91 & -48.81 & -55.39 & 5.6 & 7.0 & 5.8 \\
\hline Manga Mandi & MM & bdl & 0.56 & 0.07 & -8.70 & -7.20 & -7.80 & -56.35 & -42.54 & -48.37 & 5.0 & 5.7 & 5.4 \\
\hline Waran Piranwala & WP & bdl & 0.16 & 0.05 & -8.30 & -7.44 & -8.01 & -52.92 & -43.68 & -47.91 & 4.9 & 5.8 & 5.4 \\
\hline Kot Asad Ullah & KAD & bdl & 2.42 & 0.70 & -8.17 & -7.25 & -8.64 & -52.92 & -43.68 & -47.91 & 5.3 & 5.6 & 5.5 \\
\hline Kalalanwala & KLW & bdl & 0.50 & 0.12 & -8.70 & -7.65 & -8.27 & -60.68 & -47.0 & -52.85 & 5.2 & 5.8 & 5.5 \\
\hline Muffat Pura & MPU & 0.14 & 0.25 & 0.18 & -8.10 & -7.90 & -8.01 & -51.0 & -50.35 & -50.6 & 5.7 & 5.7 & 5.7 \\
\hline Araiyan Da Khu & ARK & bdl & 0.50 & 0.13 & -7.87 & -7.22 & -7.57 & -56.0 & -44.42 & -48.9 & 5.0 & 5.6 & 5.3 \\
\hline Deena Nath & $\mathrm{DN}$ & bdl & 0.23 & 0.07 & -8.13 & -7.20 & -7.75 & -52.0 & -46.48 & -49.25 & 5.0 & 5.5 & 5.3 \\
\hline Nathe Khalsa & NK & bdl & 2.80 & 0.60 & -8.37 & -8.20 & -8.27 & -54.79 & -45.29 & -51.81 & 5.8 & 6.3 & 6.0 \\
\hline Kot Ashraf & KA & bdl & 0.03 & 0.01 & -8.70 & -7.50 & -8.10 & -48.76 & -45.71 & -47.5 & 5.6 & 5.7 & 5.6 \\
\hline Bahi Pheru & $\mathrm{BP}$ & 0.02 & 0.04 & 0.03 & -8.55 & -7.91 & -8.46 & -56.35 & -50.47 & -52.6 & 5.3 & 5.6 & 5.4 \\
\hline Jamber Klan & JK & bdl & 0.60 & 0.30 & -7.80 & -7.70 & -7.75 & -57.0 & -46.48 & -49.25 & 3.7 & 3.9 & 3.8 \\
\hline Rehman Pura & RPNA & 0.01 & 0.03 & 0.02 & -8.28 & -7.30 & -7.79 & -50.59 & -49.91 & -50.25 & 3.7 & 3.8 & 3.7 \\
\hline Cantt Colony & $\mathrm{CCO}$ & 0.15 & 0.22 & 0.20 & -9.60 & -9.32 & -9.18 & -48.47 & -47.09 & -47.78 & 5.5 & 5.6 & 5.5 \\
\hline Zaheer Abad & ZAB & 0.03 & 0.03 & 0.03 & -7.84 & -7.00 & -7.58 & -59.83 & -52.43 & -54.79 & 4.3 & 4.7 & 4.5 \\
\hline
\end{tabular}

"bdl" means below detection limit.

Detection limits for $\mathrm{NO}_{3}^{-}-\mathrm{N}$, and $\mathrm{Fe}$ are 0.05 and 0.01 , respectively.

ard deviation was $8.5 \%$ for $20 \mathrm{ppb}$ of the solution in this method. $\mathrm{As}^{\mathrm{V}}$ is calculated from the concentration difference between the total As and As ${ }^{\mathrm{III}}$. The detection limit was determined from the lowest concentration of the standard solution giving the optical peak.

Sulfate was extracted as $\mathrm{BaSO}_{4}$ by adding $10 \% \mathrm{BaCl}_{2}$ solution in water samples for sulfur isotope analysis. The precipitated $\mathrm{BaSO}_{4}$ was collected on a $0.45 \mu \mathrm{m}$ membrane filter paper, dried, and ground together with $\mathrm{SiO}_{2}$ and $\mathrm{V}_{2} \mathrm{O}_{5}$. The sample powder was reduced to produce $\mathrm{SO}_{2}$ gas by heating at $1120^{\circ} \mathrm{C}$ following the method by Yanagisawa and Sakai (1983). To analyze the sulfur isotopes of coal, the sample was processed according to the procedure modified from Nakai and Jensen (1967), and Ohizumi et al., (1997). Two grams of coal was accurately weighed and combusted at $900^{\circ} \mathrm{C}$ in a vacuum line. The resulting gases were oxidized in $3 \% \mathrm{H}_{2} \mathrm{O}_{2}$ solution to produce sulfate ions. The obtained solution was passed through a $0.45 \mu \mathrm{m}$ membrane filter and the dissolved sulfates were recovered via $\mathrm{BaSO}_{4}$ precipitation using the 
Table 2. Ranges of analytical data of groundwaters classified by the well depth and canal water

\begin{tabular}{|c|c|c|c|c|c|c|c|c|c|c|c|c|c|}
\hline & \multirow[t]{2}{*}{ Unit } & \multicolumn{3}{|c|}{ Shallow $(n=123)$} & \multicolumn{3}{|c|}{ Middle $(n=14)$} & \multicolumn{3}{|c|}{ Deep $(n=8)$} & \multicolumn{3}{|c|}{ Canal water $(n=2)$} \\
\hline & & Min & $\operatorname{Max}$ & Mean & Min & $\operatorname{Max}$ & Mean & Min & Max & Mean & Min & Max & Mean \\
\hline $\mathrm{EC}$ & $\mathrm{mS} / \mathrm{cm}$ & 0.4 & 4.6 & 2.6 & 0.2 & 2.2 & 0.8 & 0.5 & 1.9 & 1.10 & 0.5 & 0.7 & 0.6 \\
\hline $\mathrm{pH}$ & & 7.3 & 8.8 & 8.0 & 7.1 & 8.7 & 8.0 & 6.9 & 8.7 & 7.9 & 7.5 & 7.6 & 7.6 \\
\hline Temperaure & ${ }^{\circ} \mathrm{C}$ & 26 & 28 & 27 & 24 & 27 & 26 & 23 & 24 & 23 & 27 & 27 & 27 \\
\hline $\mathrm{HCO}_{3}^{-}$ & $\mathrm{mg} / \mathrm{L}$ & 195 & 1280 & 652 & 153 & 732 & 371 & 146 & 671 & 360 & 366 & 430 & 400 \\
\hline $\mathrm{SO}_{4}{ }^{2-}$ & $\mathrm{mg} / \mathrm{L}$ & 38.0 & 960 & 257 & 24.0 & 480 & 125 & 32.0 & 341 & 150 & 36.0 & 72.0 & 54.0 \\
\hline $\mathrm{Cl}^{-}$ & $\mathrm{mg} / \mathrm{L}$ & 2.00 & 415 & 175 & 4.00 & 250 & 58.0 & 10.0 & 160 & 63.0 & 10.0 & 15.0 & 12.0 \\
\hline $\mathrm{PO}_{4}{ }^{3-}$ & $\mathrm{mg} / \mathrm{L}$ & bdl & 2.18 & 0.30 & bdl & bdl & bdl & bdl & bdl & bdl & bdl & bdl & bdl \\
\hline $\mathrm{Br}^{-}$ & $\mathrm{mg} / \mathrm{L}$ & bdl & 1.12 & 0.40 & bdl & 0.54 & 0.20 & 0.40 & 0.32 & 0.24 & bdl & bdl & bdl \\
\hline $\mathrm{NO}_{3}-\mathrm{N}$ & $\mathrm{mg} / \mathrm{L}$ & bdl & 46.00 & 9.00 & bdl & 0.70 & 0.20 & bdl & 0.84 & 0.30 & bdl & bdl & bdl \\
\hline $\mathrm{F}^{-}$ & $\mathrm{mg} / \mathrm{L}$ & 0.11 & 22.8 & 6.30 & 0.25 & 4.20 & 1.50 & 0.50 & 3.10 & 1.10 & 1.70 & 2.28 & 2.00 \\
\hline $\mathrm{Ca}^{2+}$ & $\mathrm{mg} / \mathrm{L}$ & 2.0 & 138 & 32.0 & 19.0 & 73.0 & 45.0 & 6.0 & 86.0 & 53.0 & 60.0 & 66.0 & 63.0 \\
\hline $\mathrm{Mg}^{2+}$ & $\mathrm{mg} / \mathrm{L}$ & 1.44 & 65.0 & 14.7 & 5.5 & 39.6 & 18.0 & 5.0 & 35.0 & 18.0 & 2.0 & 49.0 & 24.0 \\
\hline $\mathrm{Na}^{+}$ & $\mathrm{mg} / \mathrm{L}$ & 12.0 & 1060 & 630 & 16.0 & 322 & 150 & 23.0 & 306 & 150 & 12.0 & 19.0 & 16.0 \\
\hline $\mathrm{K}^{+}$ & $\mathrm{mg} / \mathrm{L}$ & 2.7 & 46.8 & 5.2 & 2.0 & 8.6 & 5.4 & 4.0 & 8.6 & 6.0 & 20 & 28 & 24 \\
\hline $\mathrm{SiO}_{2}$ & $\mathrm{mg} / \mathrm{L}$ & 7.4 & 37 & 22.3 & 10 & 28.6 & 22 & 11 & 30 & 20.5 & 26 & 29 & 27 \\
\hline As & $\mu \mathrm{g} / \mathrm{L}$ & 1.0 & 2400 & 123 & 14 & 392 & 72 & 8.0 & 611 & 139 & 1.0 & 1.0 & 1.0 \\
\hline
\end{tabular}

"bdl" means below detection limit.

Detection limits for $\mathrm{Br}^{-}, \mathrm{NO}_{3}{ }^{-}-\mathrm{N}_{\text {and }} \mathrm{PO}_{4}{ }^{3-}$ are $0.02,0.05$ and 0.025 , respectively.

same procedure as that for groundwater. The sulfur isotope ratio was measured using a mass spectrometer VG SIRA 10. The obtained isotope ratios are expressed in the familiar delta notation $\delta^{34} \mathrm{~S}$, referring to the CDT (Canyon Diablo Troilite) scale and defined by Eq. (1). The analytical precision for $\delta^{34} \mathrm{~S}$ was $< \pm 0.2 \%$.

$$
\delta^{34} S=\left[\frac{\left({ }^{34} \mathrm{~S}_{\text {sample }} /{ }^{32} \mathrm{~S}_{\text {sample }}\right)}{\left({ }^{34} \mathrm{~S}_{\text {standard }} /{ }^{32} \mathrm{~S}_{\text {standard }}\right)}-1\right] \times 1000
$$

Oxygen isotope ratios $\left({ }^{18} \mathrm{O} /{ }^{16} \mathrm{O}\right)$ were measured by $\mathrm{H}_{2} \mathrm{O}-\mathrm{CO}_{2}$ equilibration method originally developed by Epstein and Mayeda (1953), using an online vacuum system attached to a mass spectrometer (VG-PRISM, Micromass). The analytical error was within $0.1 \%$. Hydrogen isotope ratios $(\mathrm{D} / \mathrm{H})$ were determined by the online $\mathrm{Cr}$ reduction method (Itai and Kusakabe, 2004) attached with a mass spectrometer (VG-SIRA10, Micromass). The analytical error was within $0.5 \%$.

The Devarda's alloy/ammonia protocol, developed by Sigma et al. (1997), was used for pretreatment of $\mathrm{NO}_{3}{ }^{-}-$ $\mathrm{N}$ isotope analysis. Nitrogen isotope analysis was carried out using an online elemental analyzer interfaced with an isotope ratio mass spectrometer (EA-IRMS). Based on the multiple analyses of laboratory standards $\left(\mathrm{KNO}_{3}\right.$, $\left(\mathrm{NH}_{4}\right)_{2} \mathrm{SO}_{4}$, and DL-alanine), the precision of the analytical data was $<0.20 \%$.

To estimate the equilibrium condition of the minerals possibly controlling the soluble chemical species, saturation indices were calculated using an internet-based version of the USGS program PHREEQ (Parkhurst, 1995).

\section{RESULTS}

Analytical results of all water samples are listed in Appendix. Groundwater samples were categorized into three groups for convenience according to the well depth; shallow (20-27 m), middle (40-80 m) and deep (80-200 $\mathrm{m})$. Geochemical characteristics of the groundwater are described in the following.

\section{Major constituents}

Analytical results of major and stable isotope ratios are summarized according to location in Table 1. The chemistry is summarized according to well depth in Table 2. Chemistry of the groundwater showed large variation in the concentration ranges, however, many of those contained high salinity. As described below, the ranges of each ion overlapped among the groundwaters from the different depths; the highest concentration of major anions and $\mathrm{Na}^{+}$were almost twice as high in the shallow groundwaters than in the middle and deep groundwaters.

The shallow groundwaters gave the widest range of EC within 0.4 and $4.6 \mathrm{mS} / \mathrm{cm}$, and most of those have EC $>2.0 \mathrm{mS} / \mathrm{cm}$. The alkalinity calculated as $\mathrm{HCO}_{3}^{-}$, was $195-1280 \mathrm{mg} / \mathrm{L}$ and sulfate ranged from 38.0 to $960 \mathrm{mg} /$ $\mathrm{L}$, such that $35 \%$ of the analyzed groundwaters exceeded the WHO guideline value $(250 \mathrm{mg} / \mathrm{L})$. Sulfate and bicarbonate were the most abundant anions. The $\mathrm{Cl}^{-}$ranged from 2.0 to $415 \mathrm{mg} / \mathrm{L}$. Sodium, the most dominant cation, was up to $1,060 \mathrm{mg} / \mathrm{L}$, while $\mathrm{Ca}^{2+}$ concentrations were low, ranging from 2.0 to $140 \mathrm{mg} / \mathrm{L}$ with a mean value of $32.0 \mathrm{mg} / \mathrm{L}$.

Electric conductivity of the middle groundwaters was $0.2-2.2 \mathrm{mS} / \mathrm{cm}, \mathrm{SO}_{4}{ }^{2-} 24.0-480 \mathrm{mg} / \mathrm{L}$, alkalinity (as 
$\mathrm{HCO}_{3}{ }^{-}$) $153-732 \mathrm{mg} / \mathrm{L}, \mathrm{Na}^{+}$up to $322 \mathrm{mg} / \mathrm{L}, \mathrm{Ca}^{2+} 19-73$ $\mathrm{mg} / \mathrm{L}$ with a mean value of $45 \mathrm{mg} / \mathrm{L}$, and $\mathrm{Cl}^{-}$up to 250 $\mathrm{mg} / \mathrm{L}$. Groundwater from the deep aquifers showed narrow ranges of analytical data compared with those of shallow and middle groundwaters; EC 0.5-1.9 mS/cm, $\mathrm{SO}_{4}{ }^{2-}$ $32.0-341 \mathrm{mg} / \mathrm{L}$, alkalinity $146-671 \mathrm{mg} / \mathrm{L}, \mathrm{Na}^{+}$up to 306

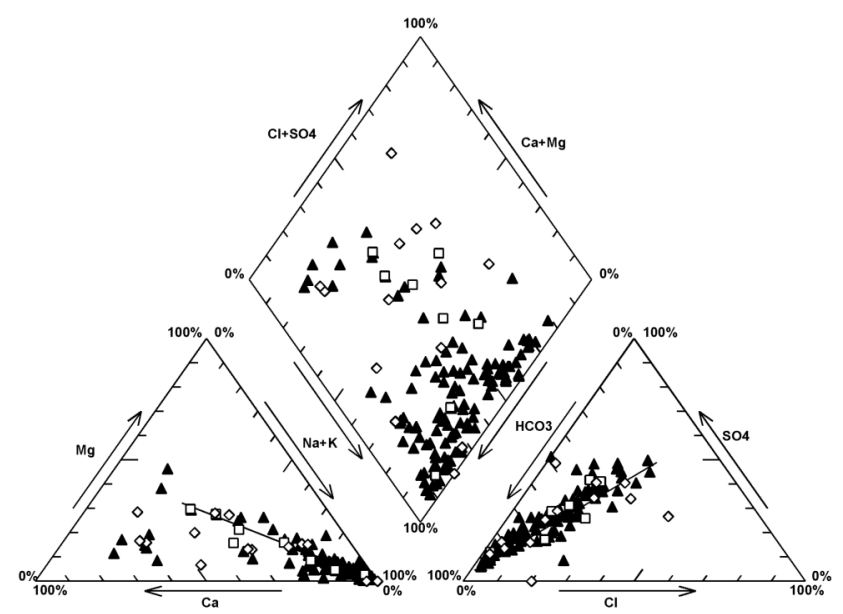

Fig. 2. Piper diagram showing the chemical compositions of groundwater samples. Solid triangles are symbols for shallow, diamond for middle, and square for deep groundwaters. $\mathrm{mg} / \mathrm{L}, \mathrm{Ca}^{2+} 6.0-86 \mathrm{mg} / \mathrm{L}$, and $\mathrm{Cl}^{-}$up to $160 \mathrm{mg} / \mathrm{L}$. The high $\mathrm{EC}$ and high concentration of the above dissolved species in shallow groundwater show that the shallow groundwater could be easily affected by the human activities.

More than half of the samples had $\mathrm{Na}^{+}-\mathrm{HCO}_{3}{ }^{-}$dominant type chemistry (Fig. 2). The classification based on major ions does not depend on the well depth. However, $\mathrm{Ca}^{2+}$ and $\mathrm{Mg}^{2+}$ tend to be slightly higher in the middle and deep groundwaters than in the shallow groundwater. Despite this, the groundwaters containing high amounts of dissolved species appear mostly from the shallow wells. The trilinear diagram showing anion composition in Fig. 2 gives the linear relationship for the anion composition between $\mathrm{HCO}_{3}{ }^{-}$and $\mathrm{Cl}^{-}+\mathrm{SO}_{4}{ }^{2-}$, suggesting that the latter two have common origins as major contaminants, e.g., household waste and fertilizers. The waters were in neutral to alkaline $\mathrm{pH}$ of 7.1-8.7.

The two canal water samples had EC $0.5-0.7 \mathrm{mS} / \mathrm{cm}$, $\mathrm{pH} 7.3$, and $\mathrm{SO}_{4}{ }^{2-} 36.0-72.0 \mathrm{mg} / \mathrm{L}$, alkalinity $427 \mathrm{mg} / \mathrm{L}$, $\mathrm{Na}^{+} 12.0-19.0 \mathrm{mg} / \mathrm{L}, \mathrm{Ca}^{2+} 60.0-66.0 \mathrm{mg} / \mathrm{L}^{2}$ and $\mathrm{Cl}^{-} 10.0-$ $15.0 \mathrm{mg} / \mathrm{L}$. The concentrations of the soluble components were much lower than the average values of the studied groundwaters with the exception of $\mathrm{Ca}^{2+}$.

High $\mathrm{NO}_{3}{ }^{-}-\mathrm{N}$ concentrations were observed in shallow groundwaters, which can easily be affected by land
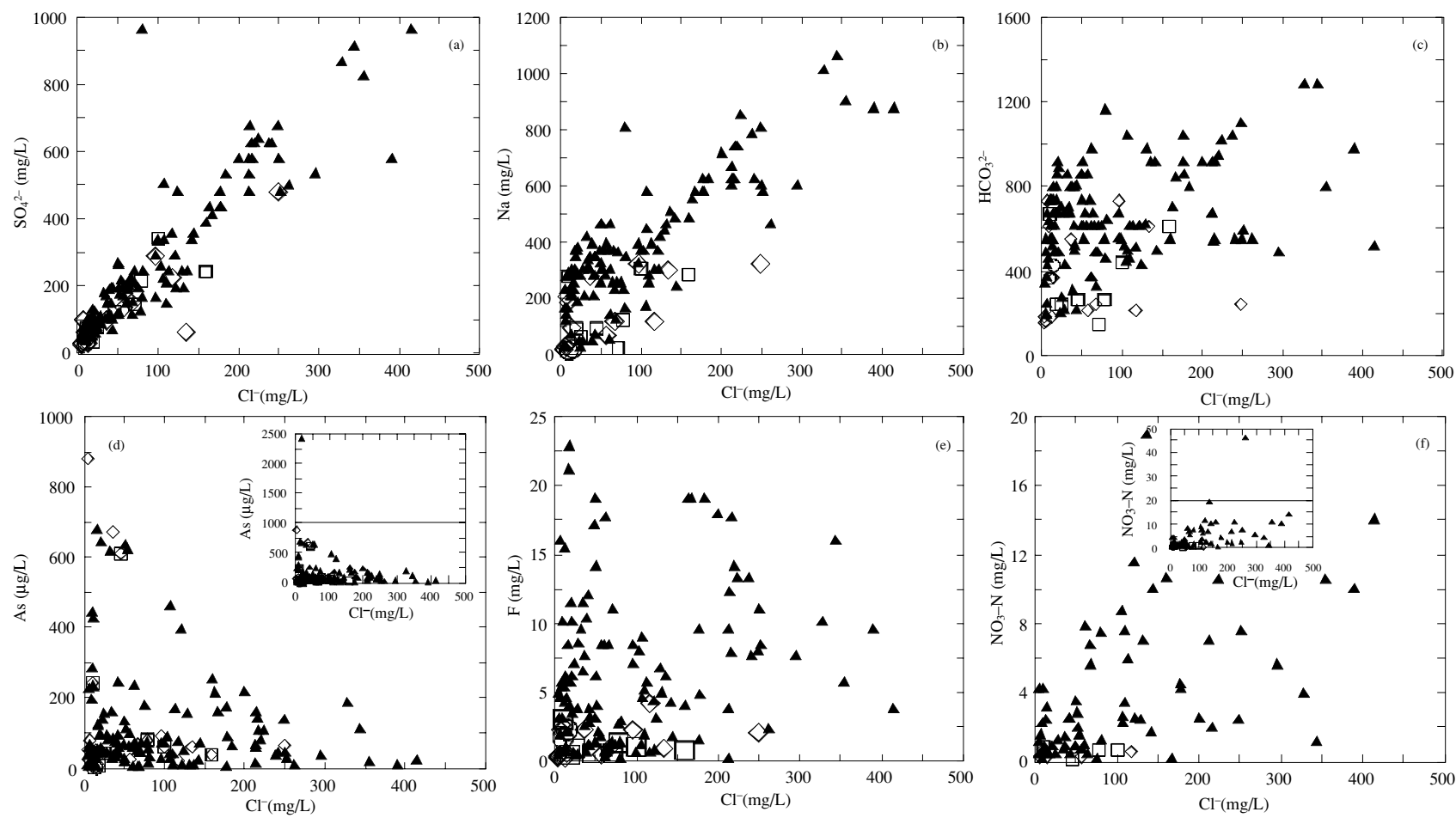

Fig. 3. Relationships of $\mathrm{Cl}^{-}$vs. $\mathrm{SO}_{4}(a), \mathrm{Na}^{+}(b), \mathrm{HCO}_{3}(c), A s(d), \mathrm{F}^{-}(e)$ and $\mathrm{NO}_{3}-\mathrm{N}(f)$. Circles are symbols for canal water and the rest of the symbols are the same as those in Fig. 2. 


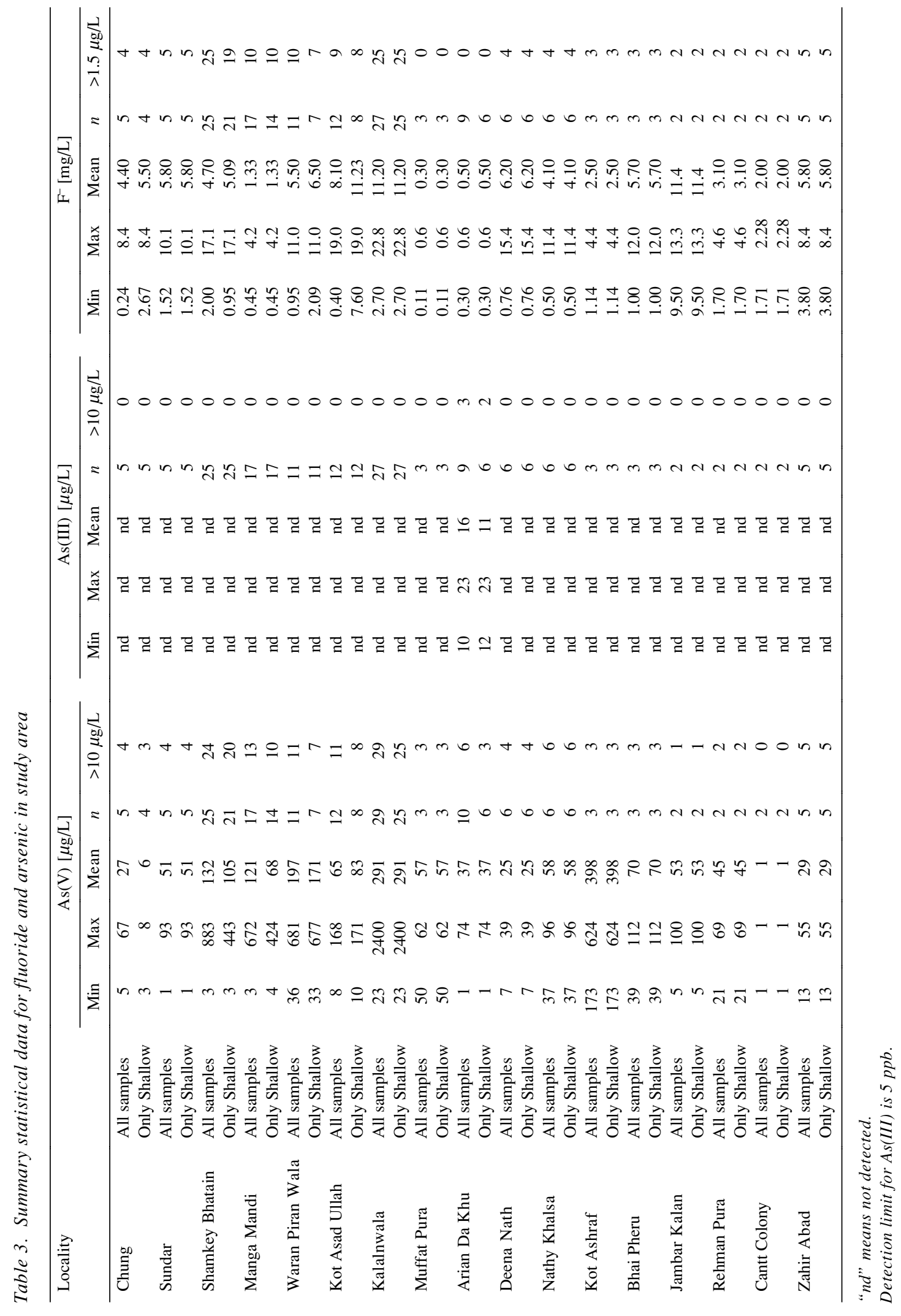



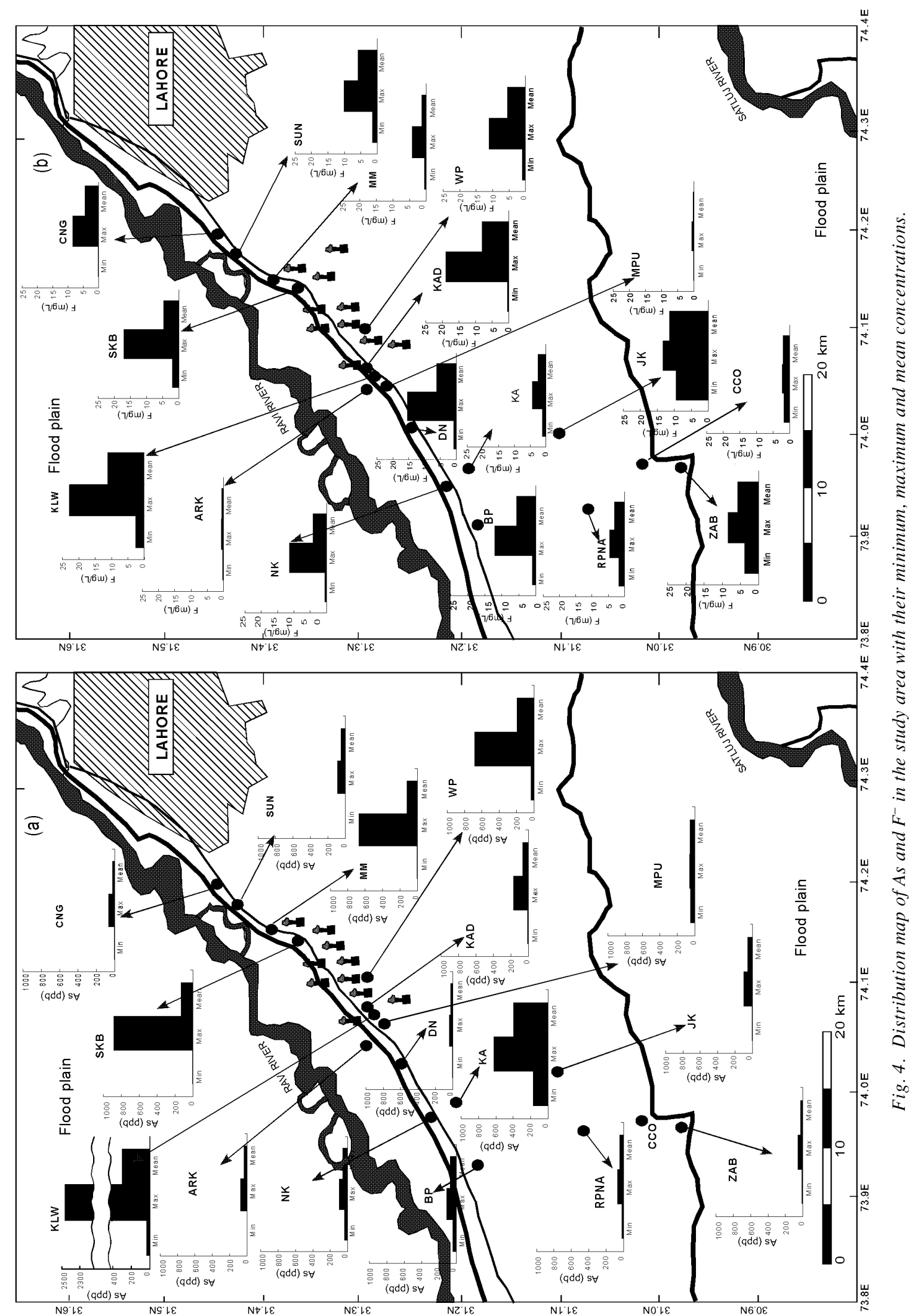

High arsenic and fluoride contaminated groundwater from East Punjab, Pakistan 221 
use. Six of them contained $\mathrm{NO}_{3}{ }^{-}-\mathrm{N}$ in excess of the WHO standard $(10 \mathrm{mg} / \mathrm{L})$ for drinking water. The highest concentration of $\mathrm{NO}_{3}{ }^{-}-\mathrm{N}$ was $46 \mathrm{mg} / \mathrm{L}$. Middle and deep waters had $\mathrm{NO}_{3}{ }^{-}-\mathrm{N}$ of $<10 \mathrm{mg} / \mathrm{L}$ (WHO standard), with the exception of two samples from the middle depth. The absence of $\mathrm{NO}_{3}{ }^{-}-\mathrm{N}$ in the deep waters would not be related to $\mathrm{NO}_{3}{ }^{-}$reduction as the groundwaters showed Eh values, up to $775 \mathrm{mV}$ (Table 1). It is more likely due to the lack of nitrogen pollution at depths $>30 \mathrm{~m}$.

Fe concentration was low in the studied groundwaters in accordance with the highly positive Eh, indicating the oxidizing conditions prohibit high Fe dissolution. Most of the studied groundwater showed Fe concentrations below the detection limit, $0.01 \mathrm{mg} / \mathrm{L}$. Only twelve samples had higher Fe, i.e., more than the WHO standard of $0.3 \mathrm{mg} / \mathrm{L}$, and the maximum concentration was $2.8 \mathrm{mg} / \mathrm{L}$ at depth of $20-27 \mathrm{~m}$.

The relationships between $\mathrm{Cl}^{-}$vs. $\mathrm{SO}_{4}{ }^{2-}, \mathrm{Na}^{+}, \mathrm{NO}_{3}{ }^{-}-$ $\mathrm{N}$, and $\mathrm{HCO}_{3}{ }^{-}$, are given in Figs. 3 a to 3 f. Sulfate, $\mathrm{Na}^{+}$, $\mathrm{HCO}_{3}{ }^{-}$and $\mathrm{NO}_{3}{ }^{-}-\mathrm{N}$ concentrations show positive correlations with $\mathrm{Cl}^{-}$(Figs. 3a, 3b, 3c, and 3f). Thus, among these elements the pollutant source(s) are either identical or the courses are similar.

\section{Arsenic}

Arsenic concentrations in the groundwater samples widely range from 1 to $2400 \mu \mathrm{g} / \mathrm{L}$. The concentration of this element in the two canal water samples was $1 \mu \mathrm{g} / \mathrm{L}$. Of 123 shallow groundwaters, 11 (ARK-1, 2, MM-4, 5, 8, 9, DN-1, 3, SKB-12, JK-2, and CNG-1, Appendix) contained $<10 \mu \mathrm{g} / \mathrm{L}$ of As. One common feature among these groundwater samples was that they contain high $\mathrm{NO}_{3}{ }^{-}-\mathrm{N}$, e.g., MM-5 was amongst the highest containing $\mathrm{NO}_{3}{ }^{-}-\mathrm{N}$. In the middle groundwaters, As ranged from 22 to $91 \mu \mathrm{g} / \mathrm{L}(n=14)$ with one exception, ARK-8, which contains $881 \mu \mathrm{g} / \mathrm{L}$ As and has an exceptionally low $\mathrm{SO}_{4}{ }^{2-}$ concentration $(29 \mathrm{mg} / \mathrm{L})$. The deep groundwaters $(n=8)$ had a $8-80 \mu \mathrm{g} / \mathrm{L}$ range of As cnocentration with the exception of two samples, KLW-2 and MM-13, having As concentrations 242 and $611 \mu \mathrm{g} / \mathrm{L}$ respectively.

Enormously high concentrations of As were found from shallow-well waters in four villages from the western and eastern part of the study area; $2400 \mu \mathrm{g} / \mathrm{L}$ in Kalalanwala and Kot Asad Ullah (KLW and KAD have different names but share residential areas), $883 \mu \mathrm{g} / \mathrm{L}$ in Shamkey Bhatian (SKB), $672 \mu \mathrm{g} / \mathrm{L}$ in Manga Mandi $(\mathrm{MM})$, and $681 \mu \mathrm{g} / \mathrm{L}$ in Waran Piran Wala (WP) (Table 3 and Fig. 4a). These four villages are located near the area where brick kilns are concentrated. The maximum As concentrations of groundwaters in the villages distributed toward west to southwest from the kiln area are between 50 and $112 \mu \mathrm{g} / \mathrm{L}$ except in Kot Ashraf (KA) where the maximum concentration is $625 \mu \mathrm{g} / \mathrm{L}$. At Chung (CNG), $15 \mathrm{~km}$ away from the main Lahore City, the groundwaters
Table 4. Nitrogen isotope data

\begin{tabular}{clcc}
\hline Sr No. & Sample ID & $\mathrm{NO}_{3}-\mathrm{N}(\mathrm{mg} / \mathrm{L})$ & $\delta^{15} \mathrm{~N}(\%$ o air $)$ \\
\hline 1 & MM-2 & 8.68 & 30.0 \\
2 & MM-3 & 7.42 & 14.0 \\
3 & MM-4 & 5.60 & 13.0 \\
4 & MM-5 & 46.00 & 25.0 \\
5 & MM-8 & 6.72 & 12.5 \\
6 & KLW-16 & 10.64 & 15.0 \\
7 & DN-3 & 18.90 & 12.5 \\
8 & DN-5 & 3.36 & 9.4 \\
9 & KA-3 & 11.48 & 8.1 \\
10 & ZAB-1 & 7.00 & 5.7 \\
11 & ZAB-2 & 7.56 & 5.0 \\
12 & ZAB-3 & 5.60 & 5.0 \\
13 & ZAB-4 & 14.00 & 5.0 \\
14 & ZAB-5 & 10.50 & 3.5 \\
15 & ARK-5 & 7.84 & 11.0 \\
16 & SKB-6 & 4.20 & 10.0 \\
17 & SKB-14 & 3.50 & 12.5 \\
18 & SKB-22 & 3.08 & 11.9 \\
19 & JK-1 & 10.50 & 15.0 \\
20 & JK-2 & 10.00 & 14.5 \\
21 & RPNA-2 & 10.00 & 7.2 \\
22 & Urea-1 & na & 1.4 \\
23 & Urea-2 & na & 0.9 \\
24 & Urea-3 & na & 1.6 \\
\hline
\end{tabular}

"na" means not analyzed.

had As concentrations up to $67 \mu \mathrm{g} / \mathrm{L}$, while those in Sundar (SUN) had $90 \mu \mathrm{g} / \mathrm{L}$ As. Such a distribution of As concentrated groundwaters can support the previously proposed hypothesis that wet and dry deposition of As derived from combusted coals in the brick kilns is one of the contributing factors to high As and $\mathrm{F}^{-}$in the study area (Farooqi et al., 2007). On the other hand, canal waters (Cantt Colony, CCO) had As values $<1 \mu \mathrm{g} / \mathrm{L}$, implying that the surface running water is not seriously contaminated by As.

Voltammetry demonstrated that $97.3 \%$ of the 147 samples did not contain detectable amounts of As ${ }^{\mathrm{III}}$. Only the remaining 4 groundwaters contained detectable As ${ }^{\mathrm{III}}$. Those were found in the groundwater from the village ARK (Arain Da Khu), where the maximum concentration of $\mathrm{As}^{\mathrm{III}}$ was $23 \mu \mathrm{g} / \mathrm{L}$ in $56 \mu \mathrm{g} / \mathrm{L}$ total As. Two of the four samples were from the shallow wells (ARK-1, 3), while the other two were from the middle (ARK-6) and deep (ARK-9) wells. The chemical compositions of these waters were mostly similar to those of the other waters collected from this village, where the EC value is $0.2-$ $1.0 \mathrm{mS} / \mathrm{cm}$ and $\mathrm{pH}$ is neutral to alkaline. This village is the only one located in the flood plain among the studied villages, thus, its geographical location is probably related to the appearance of $\mathrm{As}^{\mathrm{III}}$.

Water soluble As in fertilizers (DAP) is estimated to 
Table 5. Fluoride and As concentrations in coals and fertilzers

\begin{tabular}{|c|c|c|c|c|c|}
\hline & \multicolumn{2}{|c|}{ Coals } & & \multicolumn{2}{|c|}{ Fertilizers } \\
\hline & F (Total) & As (Total) & & F (Leachable) & As (Leachable) \\
\hline Coal-1 & 9.32 & 12 & DAP- 1 & 180 & 5 \\
\hline Coal-2 & 5.12 & 8 & DAP-2 & 250 & 7 \\
\hline Coal-3 & 10.2 & 4 & DAP-3 & 255 & 8 \\
\hline Coal-4 & 20.1 & 5 & DAP-4 & 120 & 10 \\
\hline Coal-5 & 8.03 & 4 & DAP-5 & 60 & 7 \\
\hline Coal-6 & 9.04 & 6 & & & \\
\hline Coal-7 & 8.11 & 8 & & & \\
\hline Coal-8 & 10.4 & 9 & & & \\
\hline
\end{tabular}

All values are in $\mathrm{mg} / \mathrm{kg}$.

be $5-10 \mathrm{mg} / \mathrm{kg}$ with an average value of $7.4 \mathrm{mg} / \mathrm{kg}$. The coal samples contain this element ranging from 4 to 12 $\mathrm{mg} / \mathrm{kg}$ with an average value of $8 \mathrm{mg} / \mathrm{kg}$ (Table 5). Such a high concentration of As in fertilizers would be a potentially large pollutant source of surface soil and underlying groundwater associated with cultivation in the study area. The major anthropogenic introduction of As into the environment occurs by the use of pesticides in the form of calcium arsenate, arsenic acid, lead arsenate and sodium arsenate (Alloway, 1970; Woolson et al., 1971). We have not analyzed pesticides in this study; however the use of pesticides must be responsible for the high As concentrations in the local groundwater.

\section{Fluoride}

Fluoride concentrations were high in the shallow-well waters that showed the high EC values $>2.0 \mathrm{mS} / \mathrm{cm}$. The $75 \%$ of water samples exceeded the WHO standard (1.5 $\mathrm{mg} / \mathrm{L}$ ), the maximum $\mathrm{F}^{-}$content was $22.8 \mathrm{mg} / \mathrm{L}$ found in KLW. Twenty seven groundwater samples contained $<1.5$ $\mathrm{mg} / \mathrm{L} \mathrm{F}^{-}$and nine of them were from $\mathrm{MM}$, and six from ARK (Appendix), both of which are close to the kiln concentrated area. One of the $\mathrm{F}^{-}$source(s) was suggested to be from air pollutants since the local rainwater contained a certain amount of $\mathrm{F}^{-}$(Farooqi et al., 2007). However less contaminated groundwaters in MM (Manga Mandi) imply that other larger source(s) of $\mathrm{F}^{-}$must be present in this area.

Of the middle groundwaters, $63 \%$ had $\mathrm{F}^{-}$content $<1.5$ and $37 \%$ have $>1.5 \mathrm{mg} / \mathrm{L}$. The maximum concentration was up to $4.2 \mathrm{mg} / \mathrm{L}$ found in KAD. The groundwater samples from the deep wells were $<1.5 \mathrm{mg} / \mathrm{L}$ with the only exception of one sample KLW-2 that contained $\mathrm{F}^{-} 3.1 \mathrm{mg} /$ L. The canal waters had $\mathrm{F}^{-}$content $1.7-2.3 \mathrm{mg} / \mathrm{L}$. Such an occurrence implies that the $\mathrm{F}^{-}$is derived from the surface, and this ion decreases with increasing well depth.

Figures $4 \mathrm{a}$ and $4 \mathrm{~b}$, show that the highly As contaminated areas were also contaminated by high $\mathrm{F}^{-}$, e.g., in KLW, KAD, SKB and WP, but not the same well waters.
Figure 5 shows that $\mathrm{F}^{-}$and As had a negative correlation. These facts suggest that not only one but rather more than two mechanisms and/or pollutant sources are responsible for the formation of the highly As and $\mathrm{F}^{-}$contaminated groundwaters in the study area.

From Figs. 5b, 5c, 5d and 5e, weakly positive correlations are observed between $\mathrm{F}^{-}$vs. $\mathrm{HCO}_{3}{ }^{2-}$ and $\mathrm{Na}^{+}$(Figs. $5 \mathrm{~b}$ and $5 \mathrm{c}$ ), while negative correlations exist between $\mathrm{F}^{-}$ vs. $\mathrm{Ca}^{2+}$ and $\mathrm{Mg}^{2+}$ (Figs. 5d and 5e). Such negative correlations suggest that the low $\mathrm{Ca}^{2+}$ and $\mathrm{Mg}^{2+}$ concentrations lead to occurrence of highly $\mathrm{F}^{-}$containing groundwaters. Low $\mathrm{Ca}^{2+}$ and high $\mathrm{Na}^{+}$concentrations could be explained by the cation exchange reaction in which $\mathrm{Ca}^{2+}$ originally in the water has been exchanged by $\mathrm{Na}^{+}$, or removed due to precipitation of carbonate minerals under high alkalinity (e.g., Nickson et al., 2005). Fluoride did not show good relationship with $\mathrm{pH}$ (Fig. 5f).

Air pollutants from coal combustion and phosphate fertilizers are common sources of $\mathrm{F}^{-}$in the environment (Pickering, 1985). The fertilizers contained soluble $\mathrm{F}^{-}$ ranging from 60 to $255 \mathrm{mg} / \mathrm{kg}$ with an average value of $175 \mathrm{mg} / \mathrm{kg}$, while, coal samples contained total $\mathrm{F}^{-}$ranging 5.12 to $20.1 \mathrm{mg} / \mathrm{kg}$ with an average value of $10.2 \mathrm{mg} /$ $\mathrm{kg}$ (Table 5).

\section{Stable isotopic compositions}

Oxygen and hydrogen isotopes The ranges of stable isotopic ratios of hydrogen and oxygen of the groundwater samples are summarized in Table 1 . The relationship between $\delta^{18} \mathrm{O}$ and $\delta \mathrm{D}$ of groundwaters is plotted in Fig. 6, along with those values of local rainwaters.

Oxygen isotopic ratios of the groundwater ranged within -9.6 and $-7.0 \%$, while $\delta \mathrm{D}$ within -61.9 to $-42.5 \%$. The compositions did not show any distinctive relationship to well locations or depth. The $\delta^{18} \mathrm{O}$ of canal waters ranged from -9.6 to $-9.3 \%$ and $\delta \mathrm{D}$ from -59.8 to $-52.4 \%$. The $\delta^{18} \mathrm{O}$ and $\delta \mathrm{D}$ of all studied groundwater samples fell between those of the rain and canal waters, indicating 

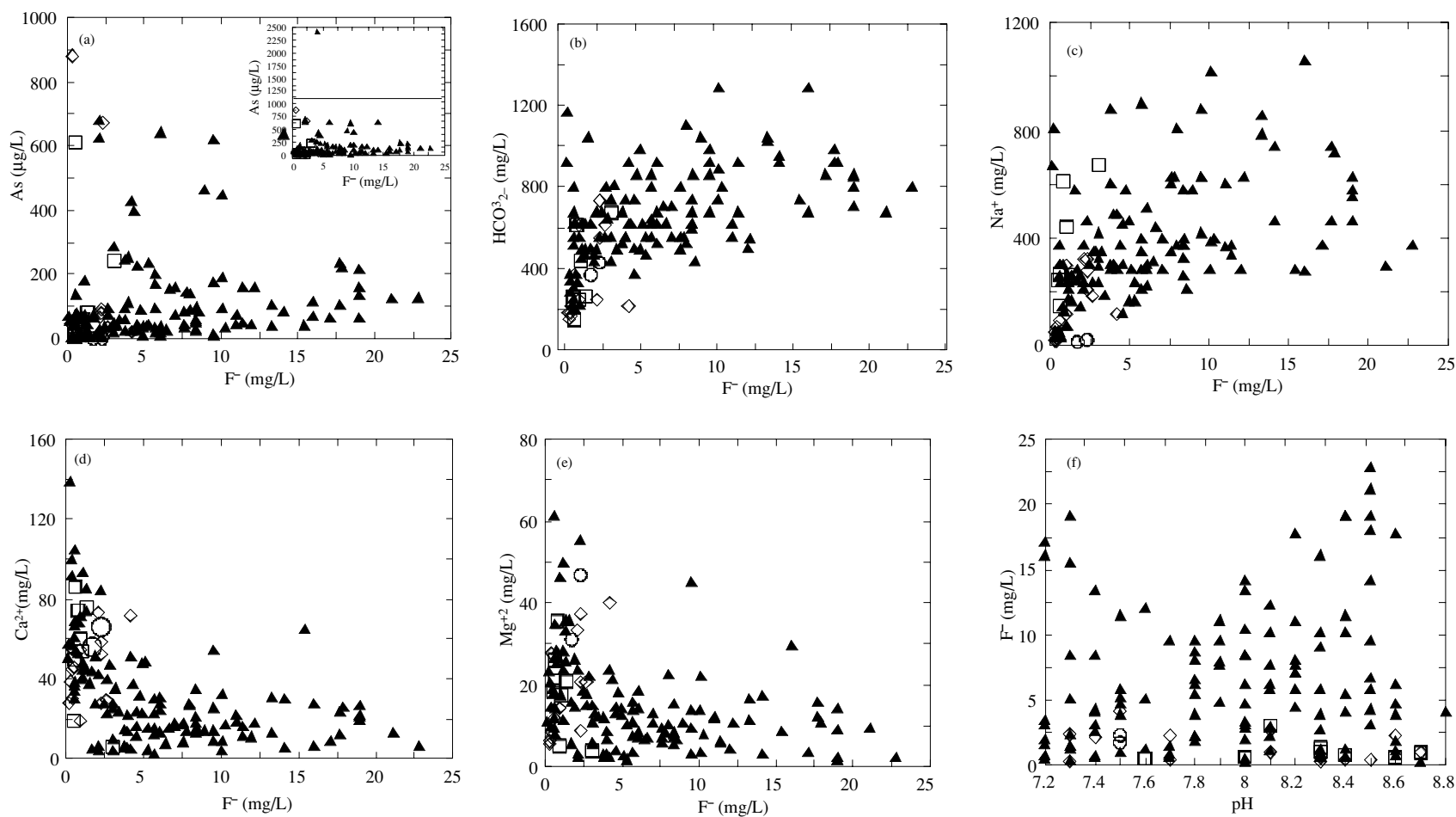

Fig. 5. Relationships of $\mathrm{F}^{-}$with $\mathrm{As}(\mathrm{a}), \mathrm{HCO}_{3}(b), \mathrm{Na}^{+}(c), \mathrm{Ca}^{2+}(d), \mathrm{Mg}^{2+}(e)$, and $\mathrm{pH}(f)$. Symbols are identical to those in Fig. 3 .

mixing between local meteoric water and the water from the river, which is mainly recharged at higher altitudes in Indian territory. The waters plot on a slope parallel to that of global meteoric water line (GMWL, $\delta \mathrm{D}=8 \times \delta^{18} \mathrm{O}+$ 10 , Fig. 6 ), indicating that evaporation was not significant in the local groundwaters.

Sulfur isotopes Sulfur isotopic composition is an efficient tool for tracing and identifying the $\mathrm{SO}_{4}{ }^{2-}$ pollutant sources. The $\delta^{34} \mathrm{~S}$ values of the studied groundwaters range from +3.7 to $+7.0 \%$, and three groups can be identified from the data (Fig. 7a); groundwaters having constant $\delta^{34} \mathrm{~S}$ values $\left(5.5-5.7 \%\right.$ ) irrespective to the $\mathrm{SO}_{4}{ }^{2-}$ concentration (A), those with high $\delta^{34} \mathrm{~S}$ values $(6.3-7.0 \%$ ) and low $\mathrm{SO}_{4}{ }^{2-}(\mathrm{B})$, those with low $\delta^{34} \mathrm{~S}$ values $(3.7-4.8 \%$ ) and high $\mathrm{SO}_{4}{ }^{2-}(\mathrm{C})$. The $\delta^{34} \mathrm{~S}$ values of rainwater $(n=3)$ range from 5.0 to $7.0 \%$. The $\delta^{34} \mathrm{~S}$ values of coal collected from the study area $(n=8)$ range within 3.5-10\%o with an average value of $6.0 \%$. The $\delta^{34} \mathrm{~S}$ values of fertilizer (DAP, $n=5$ ) ranged within 3.4-7.6\% with the mean value of $5.7 \%$.

In group $\mathrm{A}$, all samples had $\delta^{34} \mathrm{~S}$ values around 5.5$5.7 \%$ with widely varying $\mathrm{SO}_{4}{ }^{2-}$ concentrations. One of the $\mathrm{SO}_{4}{ }^{2-}$ sources must be atmospheric pollution, since rainwater and coal samples also showed average $\delta^{34} \mathrm{~S}$ value around $6.0 \%$ and $\mathrm{SO}_{4}{ }^{2-}$ concentration in the rain was $14 \mathrm{mg} / \mathrm{L}$. The range is also concordant with the aver- age $\delta^{34} \mathrm{~S}$ value of the fertilizers. In conjunction with the fact that considerable evaporation-condensation does not occur following recharge, high $\mathrm{SO}_{4}{ }^{2-}$ concentration in the groundwaters of this group must be caused by the fertilizers distributed in the study area, although the recharging water was already contaminated by airborne sulfur.

Group B is characterized by the $\delta^{34} \mathrm{~S}$ values $>6 \%$ with low $\mathrm{SO}_{4}{ }^{2-}$ concentrations $<250 \mathrm{mg} / \mathrm{L}$. The maximum $\delta^{34} \mathrm{~S}$ value is $+7.0 \%$, which is close to that of household detergents $(+8.5$ to $+13.6 \%$; Laura et al., 2004).

Group $\mathrm{C}$ groundwaters had low $\delta^{34} \mathrm{~S}$ and high $\mathrm{SO}_{4}{ }^{2-}$ concentrations. All waters of this group were obtained from the villages RPNA, JK and ZAB, located at southwest of the study area in Fig. 7b, away from the brick kiln area. The effect of atmospheric pollution and fertilizers would be smaller in this area compared to other locations in the study.

The sulfur source cannot be elucidated, since $\delta^{34} \mathrm{~S}$ values of fertilizers and air pollutants overlap. However, the $\mathrm{SO}_{4}{ }^{2-}$ in the groundwaters of the study area appears generally to have originated from fertilizers, air pollutants and household waste water including detergent used in the area.

Nitrogen isotopes Nitrate $\delta^{15} \mathrm{~N}$ was analyzed for 21 groundwaters to identify the sources of nitrogen contaminants (Table 4). Most of the groundwater samples give 


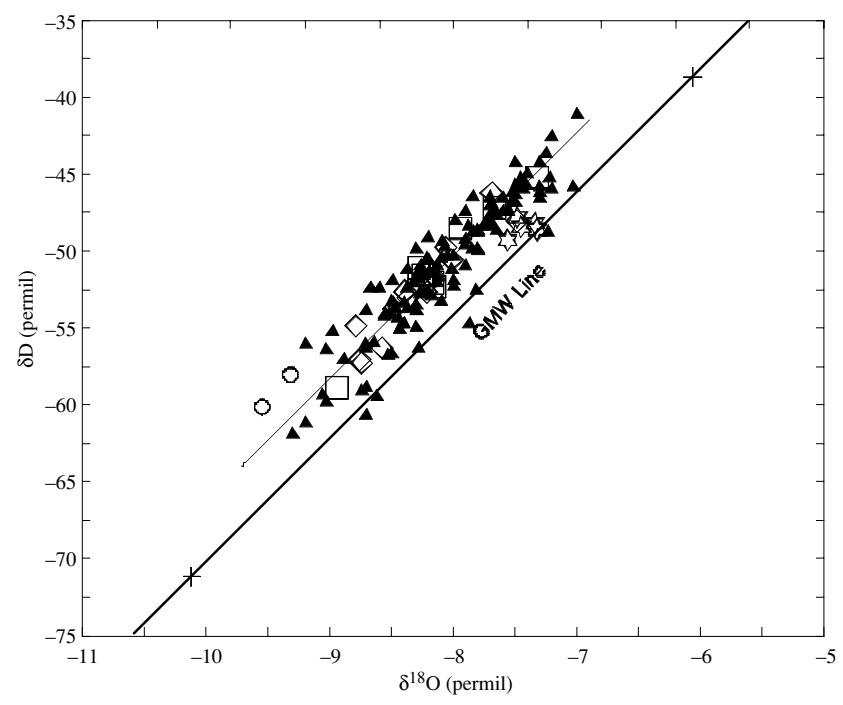

Fig. 6. Oxygen versus Hydrogen isotope ratios. Symbols are identical to those in Fig. 3.

$\delta^{15} \mathrm{~N}_{\mathrm{NO} 3}>5 \%$, with the maximum value $30 \%$ and the mean one $10 \%$. The $\delta^{15} \mathrm{~N}_{\mathrm{NO} 3}$ of the groundwater samples are in the same range of those of animal waste: for example, nitrate originating from animal excrement displays $\delta^{15} \mathrm{~N}_{\mathrm{NO} 3}$ values typically in the range within +10 to $20 \%$ (Heaton, 1986; Widory et al., 2004), and +8 to 25\% (Fogg et al., 1998). Volatilization and denitrification by microbial activities fractionate $\mathrm{N}$ isotopes such that ${ }^{15} \mathrm{~N}$ becomes enriched in soil, although those two processes cannot increase $\delta^{15} \mathrm{~N}$ by more than $10 \%$ (Gormly and Spalding, 1979). Thus, the $\delta^{15} \mathrm{~N}_{\mathrm{NO} 3}$ indicates human and animal waste distributed inside the villages as the major nitrate source.

The groundwaters from Zahir Abad (ZAB), the southwesternmost village among the studied villages, showed a narrow range of $\delta^{15} \mathrm{~N}$ from $3.5-5.7 \%$. The $\delta^{15} \mathrm{~N}$ of fertilizer samples (urea, $n=3$ ) were also analyzed, and those values were $<2 \%$, close to that of air. The range of $\delta^{15 \mathrm{~N}}$ of $\mathrm{ZAB}$ groundwaters is in concordant with that of soil organic nitrogen (e.g., Chapella 2001) and chemical fertilizers used in China (Li et al., 2007) but slightly larger than those used in this area. Since the concentration of $\mathrm{NO}_{3}{ }^{-}-\mathrm{N}$ is not very low in the analyzed waters, the soil organic nitrogen would not be the only source for this component. Denitrification of urea in the fertilizers would promote to enrich in ${ }^{15} \mathrm{~N}$ in those waters.

\section{DISCUSSIONS}

\section{Pollutant sources}

Although As and $\mathrm{F}^{-}$rich groundwaters are well known to occur naturally in many parts of world, anthropogenic
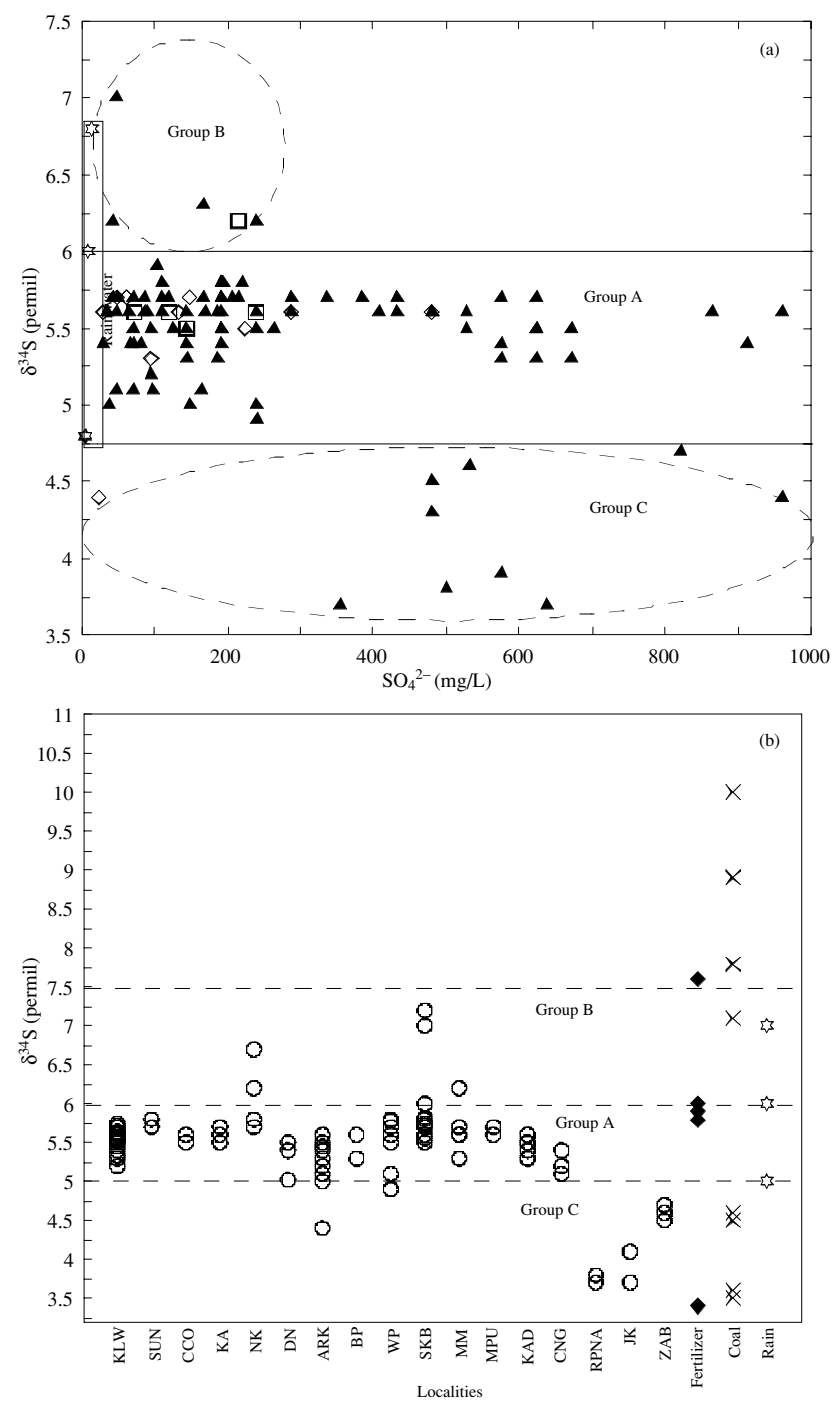

Fig. 7. The relationship between sulfur isotope ratios and sulfate concentrations (a), and the sulfur isotope ratios of groundwater samples corresponding to the sampling villages, coal, fertilizers and rainwater samples $(b)$. In (a), solid triangles are symbols for shallow, diamond for middle and square for deep groundwaters and stars are for rainwaters.

contamination cannot be excluded in the studied area.

Arsenic in ambient air in the Lahore district is 230$2230 \mathrm{ng} / \mathrm{m}^{3}$ (JICA and Pakistan EPA, 2000), which is much higher than those reported in the other areas in the world; e.g., $91-512 \mathrm{ng} / \mathrm{m}^{3}$ in Calcutta, India (Chakraborti et al., 1992), $25 \mathrm{ng} / \mathrm{m}^{3}$ in Wuhan City, China (Waldman et al., 1991), and $1.2-44 \mathrm{ng} / \mathrm{m}^{3}$ in Los Angles, USA (Rabano et al., 1989). The $\mathrm{SO}_{2}$ in the ambient air was $133-212 \mu \mathrm{g} / \mathrm{m}^{3} / \mathrm{hr}$ in Lahore (Punjab EPD, 1998-99), which is lower than the WHO guideline value for $\mathrm{SO}_{2}$ in air, i.e., $350 \mu \mathrm{g} / \mathrm{m}^{3} / \mathrm{hr}$. We also reported high concentra- 

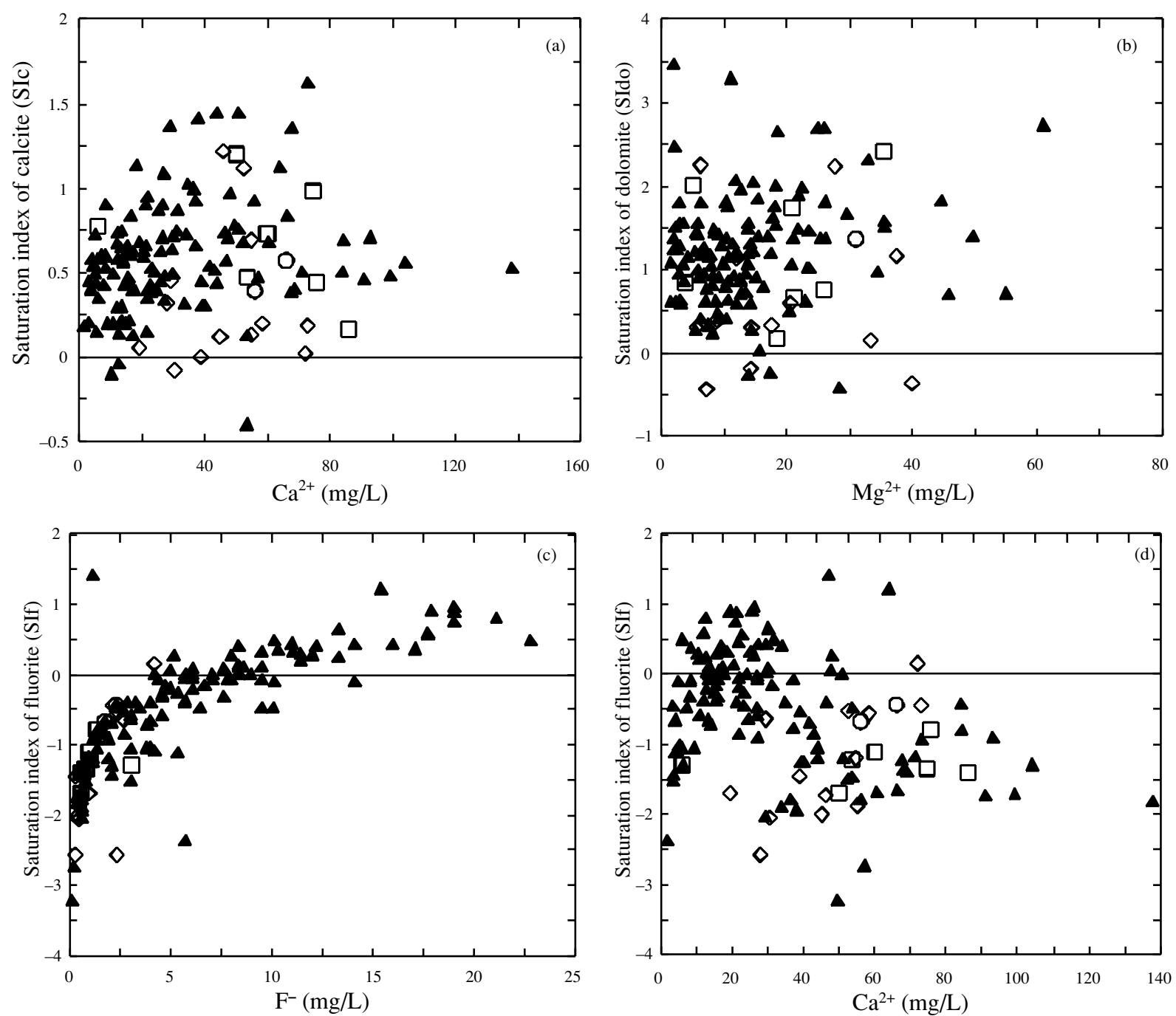

Fig. 8. Relationships between calcite saturation index $\left(S_{c}\right)$ and $\mathrm{Ca}^{2+}(a)$, dolomite saturation index and $\mathrm{Mg}^{2+}(\mathrm{b})$, fluorite saturation index $\left(S I_{f}\right)$ and $F^{-}(c)$, fluorite saturation index $\left(S I_{f}\right)$ and $\mathrm{Ca}^{2+}(d)$. Symbols are the same as those in Fig. 2.

tion of As $(<10-90 \mu \mathrm{g} / \mathrm{L})$, with $\mathrm{SO}_{4}{ }^{2-}(5-14 \mathrm{mg} / \mathrm{L})$ in the local rain (Farooqi et al., 2007). Although the concentration of $\mathrm{SO}_{2}$ in ambient air is lower than the WHO standard, the presence of As in the air and rainwater support that those elements in the studied groundwater are partly derived via ambient air.

Fluoride can be released in the environment from phosphate fertilizers, which include fluorine as an impurity (Pickering, 1985; Skjelkvale, 1994). Phosphate fertilizers commonly contain from 1.3 to $3.0 \%$ fluorine (McLaughlin et al., 1996), much higher than those analyzed here. The annual consumption of fertilizers in 1999 was 2,824 thousand metric tonnes with $129 \mathrm{~kg} / \mathrm{ha}$ cropland in Pakistan and mostly in Punjab (http:// earthtrends.wri.org). The presence of leachable $\mathrm{F}^{-}$and As in fertilizer and coal samples also shows anthropogenic contribution of fertilizers being used in the study area and combusted coal in the brick factories. Local rainwater contained $0.16-0.23 \mathrm{mg} / \mathrm{L} \mathrm{F} \mathrm{F}^{-}$, and we presumed that the $\mathrm{F}^{-}$was partly derived from combusted coal in the studied area (Farooqi et al., 2007). The presence of $\mathrm{F}^{-}$and As in coal samples (though not so high) substantiates our hypothesis of the contribution of combusted coal; however, fertilizers (DAP) consumed in the surroundings would be more important as an anthropogenic source of $\mathrm{F}^{-}$in the study area.

Controlling role of major chemistry on As and $F^{-}$behavior

High concentrations of As were found in groundwaters from shallow depths. The highly As contaminated waters were characterized by high EC values $>2 \mathrm{mS} / \mathrm{cm}, \mathrm{Na}-$ $\mathrm{HCO}_{3}{ }^{-}$dominant major chemistry and have $\mathrm{pH}>8$. As 

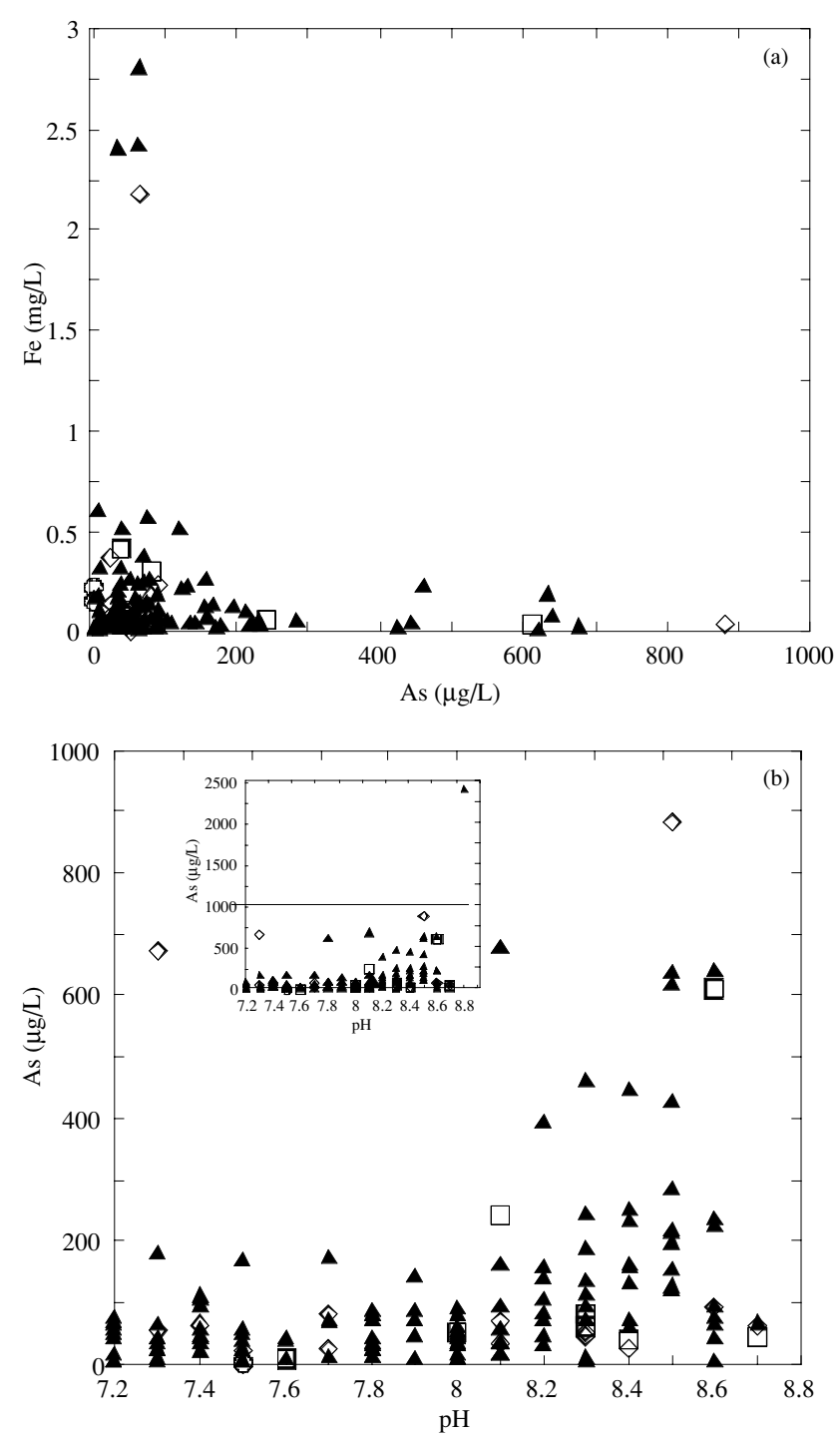

Fig. 9. Relationship between As and $\mathrm{Fe}(a)$ and $\mathrm{pH}(\mathrm{b})$. Symbols are the same as those in Fig. 2.

noted before, the As concentration increases with increasing $\mathrm{pH}$ (Fig. 9b) and $\mathrm{As}^{\mathrm{V}}$ is the dominant As species in the studied groundwaters. Naturally As contaminated groundwater is mainly caused by two different processes: oxidation of arsenic-bearing sulfide minerals (Schreiber et al., 2000) and desorption from and/or following reduction of $\mathrm{FeOOH}$ adsorbing As (Matisoff et al., 1982; Robertson, 1989; Nimick, 1998; Nickson et al., 1998, 2005; McArthur et al., 2001) in response to the increase of $\mathrm{pH}$ and decrease of redox potential of the groundwater.

Based on laboratory experiments of As adsorption on the metal oxides, such as $\mathrm{Fe}, \mathrm{Mn}$ and $\mathrm{Al}$ oxyhydroxide/ oxides (Anderson et al., 1976; Pierce and Moore, 1982; Dzombak and Morel, 1990; Gustafsson and Jacks, 1995;
Lindberg et al., 1997) and clay fractions (Jacobs et al., 1970; Manning and Goldberg, 1997), $\mathrm{As}^{\mathrm{V}}$ is most effectively adsorbed on $\mathrm{Fe}$-oxyhydroxide/oxide at weakly acidic to neutral $\mathrm{pH}$ conditions, and it is released into solution with increasing $\mathrm{pH}$ to alkaline conditions. Regardless of whether the As originates from anthropogenic source(s) or from natural substances, we can say that alkaline conditions promote the dissolution of As into the studied groundwaters.

Figure 9a shows that As and Fe have a negative correlation, and the groundwater containing $<0.2 \mathrm{mg} / \mathrm{L} \mathrm{Fe}$, contains $>400 \mu \mathrm{g} / \mathrm{L}$ As. Thus, $\mathrm{FeOOH}$, if it controls the As concentration in the studied groundwater, would fix the As to prohibit the dissolution of this element into the groundwater. As shown in Fig. 9b a positive correlation is observed between As and $\mathrm{pH}$ which has a dominant role on the As mobilization. Arsenate is desorbed from Fe oxides at alkaline pH (Dzombak, and Morel, 1990). Many researchers have pointed out that desorption of As from mineral oxides is responsible for the highly Ascontaining groundwater in Quaternary sedimentary aquifers, e.g., As release into the groundwater can occur without apparent reduction in the arid basins of Argentina (Smedley et al., 2002).

Fluoride concentration in groundwater in arid and semiarid regions is promoted by evaporation and evapotranspiration (Jacks et al., 2005). However, we pointed out that this mechanism cannot explain the case of our studied area, since $\mathrm{F}^{-}$concentrations did not have the linear relationship with $\mathrm{Cl}^{-}$(Fig. 3e), which is the most conservative component in the hydrosphere. Also, as shown in Fig. 6, plots of $\delta \mathrm{D}$ and $\delta^{18} \mathrm{O}$ were parallel to the global meteoric water line (GMWL, Fig. 6), confirming that the studied waters were not affected by evaporation and condensation. Thus, the high concentrations of $\mathrm{Cl}^{-}, \mathrm{F}^{-}$and also $\mathrm{SO}_{4}{ }^{2-}$ would be explained by one or more sources distributed on the land surface or intruded directly into the aquifer. Directly supplied pollutants and wet and dry deposition must be condensed on the land surface.

High $\mathrm{F}^{-}$concentrations were found in alkaline water, although the $\mathrm{F}^{-}$and $\mathrm{pH}$ did not show a clear correlation (Fig. 5b). As described above, $\mathrm{F}^{-}$concentration increased with decreasing $\mathrm{Ca}^{2+}$ and $\mathrm{Mg}^{2+}$ and increasing $\mathrm{Na}^{+}$concentrations under alkaline conditions. Calcium and $\mathrm{Mg}^{2+}$ concentrations were low and controlled mainly by the solubilites of calcite and dolomite due to high $\mathrm{HCO}_{3}{ }^{-}$ concentrations. As shown in Figs. 8a and 8b, most of the studied groundwaters were saturated with those minerals. The saturation index of fluorite $\left(\mathrm{SI}_{\mathrm{f}}\right)$ increased with increasing $\mathrm{F}^{-}$concentration (Fig. 8c), while $\mathrm{Ca}^{2+}$ did not show a clear relationship with $\mathrm{SI}_{\mathrm{f}}$ (Fig. 8d). Therefore, the low concentrations of $\mathrm{Ca}^{2+}$ (and probably $\mathrm{Mg}^{+}$) must promote high concentrations of $\mathrm{F}^{-}$in the studied groundwater, and that the upper limit of $\mathrm{F}^{-}$concentrations is 
controlled by fluorite solubility as seen in Fig. 8c. Low $\mathrm{Ca}^{2+}$ would also result from the intense cation exchange reaction between $\mathrm{Ca}^{2+}$ and $\mathrm{Na}^{+}$(Sarma and Rao, 1997). In the study area, the source water not only introduces As and $\mathrm{F}^{-}$, but also determine the chemistry of the groundwater. It controls the dissolution rates of the toxic substances and must play an important role in the formation of polluted groundwater.

\section{Topographic constraints}

Highly As and $\mathrm{F}^{-}$polluted groundwaters were concentrated in eastern and western part of the study area, e.g., KLW, KAD, SKB, and MM. The altitude of these villages is slightly lower than the other villages of the study area. Villages where the groundwater contains less amounts of As, are located in the surrounding area of KLW, KAD, SKB, and MM: CNG and SUN at northeast, BP at south and JK, ZAB, and RPNA at southwest. These villages are located at slightly higher altitudes $(>220 \mathrm{~m})$ than the higher polluted villages (KLW, KAD, SKB, and MM), which are situated at about $200 \mathrm{~m}$. If the surface topography was concordant with the structure of the aquifer, groundwater would flow toward topographic low. The highly As and $\mathrm{F}^{-}$polluted groundwaters are very alkaline and of $\mathrm{Na}^{-}-\mathrm{HCO}_{3}{ }^{-}$dominant type, indicating typical characteristics of groundwater chemistry in stagnant aquifers (e.g., Hinkle, 1997). Thus, it is probable that the As and $\mathrm{F}^{-}$are coincidently dissolved into the stagnant groundwater. Although we must wait evaluation of the relationship between aquifer structure and polluted groundwater formation to obtain geological profiles, the groundwater flow system, including flowing rate and direction, would deeply affect the groundwater chemistry and formation of the studied highly polluted groundwater.

\section{Conclusions}

This study demonstrates that $\mathrm{As}$ and $\mathrm{F}^{-}$contamination of groundwater is not limited to a small area comprising two adjacent villages, KLW and KAD, but widely extends to the surrounding areas. In the studied 17 villages, a population of more than 2.0 million are directly exposed to As and $\mathrm{F}^{-}$through air, surface soils and groundwater. In particular, the levels of $\mathrm{As}$ and $\mathrm{F}^{-}$in the groundwater are much higher than the WHO standards. The studied groundwaters are not only polluted by high concentrations of As and $\mathrm{F}^{-}$but also by $\mathrm{SO}_{4}{ }^{2-}, \mathrm{NO}_{3}{ }^{-}$, alkalinity and other anthropogenic pollutants. $\mathrm{Ca}^{2+}$ and $\mathrm{Mg}^{2+}$ are generally low due to the precipitation of carbonate minerals and cation exchange reactions with $\mathrm{Na}^{+}$. Low $\mathrm{Ca}^{2+}$ concentration promotes the dissolution of $\mathrm{F}^{-}$, with $\mathrm{F}^{-}$concentration being controlled by the solubility of fluorite. Speciation analysis shows that $\mathrm{As}$ is in the form of $\mathrm{As}^{\mathrm{V}}$. Given low $\mathrm{Fe}^{2+}$ concentration under positive Eh values,
As is dissolved into groundwater mainly under alkaline $\mathrm{pH}$, at which As cannot be effectively adsorbed onto $\mathrm{Fe}$ and other metal oxyhydroxide/oxides and/or clay minerals.

Our present results indicate that the main anthropogenic source of As is air pollutants derived from kiln factories, with fertilizers being a possible secondary source. Minor amounts of $\mathrm{F}^{-}$and $\mathrm{SO}_{4}{ }^{2-}$ are also derived from air pollutants; however, major sources of these components must be fertilizers. Household waste water also contributes to the high $\mathrm{SO}_{4}{ }^{2-}$, although waste water lacks $\mathrm{F}^{-}$and As. These pollutants can remain under alkaline conditions in our studied groundwaters, where major chemical composition would be controlled by the stagnant condition of the aquifer. Groundwater pollution is most serious in shallow sections of the aquifer between 20 and $30 \mathrm{~m}$ depth; however, highly polluted groundwater, especially by As occasionally occurs in the deep aquifers $>40 \mathrm{~m}$. Thus, whilst the groundwaters are grouped into three depths by convenience, are in reality probably connected, and the pollutants could migrate into the deeper part of the same aquifer. To evaluate this possibility, we should clarify the structure of the aquifers in this area, and we should plan to protect the groundwater quality in at least the deeper parts of the aquifer in this area.

Acknowledgments - We are thankful to Mr. M. Sakhawat, Director of Geoscience Laboratory, Geological Survey of Pakistan, Islamabad, for his cooperation and providing all necessary facilities for field and laboratory works. Technical support from Ms. K. Okazaki, Osaka City University, is appreciated. We also thank to Dr. X. D. Li, Osaka City University, Dr. K. Koba, Tokyo Institute of Technology, for assistance in the analysis of nitrogen isotopes, which were analyzed using the facilities at Centre for Ecological Research, Kyoto University. We thank to Dr. H. Chiba, Okayama University, for guiding fluoride analysis using an ion meter. The authors are indebted to Mr. M. Rehan-ul-Haq Siddiqui for his help during the field work and Ms. N. Haider, Geoscience Laboratory, Geological Survey of Pakistan, for laboratory assistance. Thanks are extended to Dr. M. Imran Al-Haq, University of Tokyo, for linguistic suggestions. This work was financially supported by JSPS (Scientific aid: No. 12440145) and Sumitomo Foundation.

\section{REFERENCES}

Ali, A. M., Farooq, M., Hameed, A., Afzal, M. and Brinkman, B. (1968) Reconnaissance Soil Survey of Lahore District, Soil Survey of Pakistan. Soil Survey Project of Pakistan, 207 pp.

Alloway, W. H. (1970) Agronomic control over the environmental cycling of trace elements. Adv. In. Agron. 20, 235274.

Anderson, M. A., Ferguson, J. F. and Gavis, J. (1976) Arsenate adsorption on amorphous aluminum hydroxide. J. Colloid 
Interface Sci. 54, 391-399.

Aruscavage, P. (1977) Determination of arsenic, antimony, and selenium in coal by atomic absorption spectroscopy with a graphite tube atomizer. U.S.G.S. 5, 405-408.

Bhattacharya, P., Welch, A. H., Ahmed, K. M., Jacks, G. and Naidu, R. (2004) Arsenic in groundwater of sedimentary aquifers. Appl. Geochem. 19, 163-167.

CDCP (Centers for Disease Control and Prevention) (1999) Achievements in public health, 1900-1999: fluoridation of drinking water to prevent dental caries. Morbidity and Mortality Weekly Report 48, 933-940.

Chakraborti, D., Das, D., Chatterjee, A., Jin, Z. and Jiang, S. G. (1992) Direct determination of some heavy metals in urban air particulates by electro-thermal atomic absorption spectrometry using Zeeman back-ground correction after simple acid decomposition. Part IV: Applications to Calcutta air particulates. Environ. Tech. 13, 95-100.

Chapella, H. F. (2001) Groundwater Microbiology and Geochemistry. John Wiley \& Sons, New York, 477 pp.

Cook, J. (1987) Left Bank Outfall Drain Stage I Project: Scavenger Well Studies and Pilot Project. British Geological Survey.

Crossley, H. E. (1944) Fluorine in coal. II. The determination of fluorine in coal. J. Soc. Chem. Ind. London 63, 284.

Dzombak, D. A. and Morel, F. M. M. (1990) Surface Complexation Modeling: Hydrous Ferric Oxide. John Wiley \& Sons, New York, 393 pp.

Epstein, S. and Mayeda, T. (1953) Variations of the $\delta^{18} \mathrm{O}$ content of water from natural sources. Geochim. Cosmochim. Acta 4, 213-224.

Farooqi, A., Masuda, H. and Firdous, N. (2007) Toxic fluoride and arsenic contaminated water in Lahore and Kasur districts, Punjab, Pakistan and possible contaminant sources. Environ. Pollut. 145, 839-849.

Fogg, G. E., Rolston, D. E., Decker, D. L., Louie, D. T. and Grismer, M. E. (1998) Spatial variation in nitrogen isotope values beneath nitrate contamination sources. Ground Water 36, 418-426.

Gormly, J. R. and Spalding, R. F (1979) Sources and concentrations of nitrate-nitrogen in ground water of the Central Platte Region, Nebraska. Ground Water 17, 291-301.

Greenman, D. W., Swarzenski, W. V. and Bennet, G. D. (1967) Groundwater hydrology of Punjab, West Pakistan with emphasis on problems caused by canal irrigation. U.S.G.S. Water Supp. Pap., 1608-H.

Gustafsson, J. P. and Jacks, G. (1995) Arsenic geochemistry in forested soil profiles as revealed by solid-phase studies. Appl. Geochem. 10, 307-316.

Heaton, T. H. E. (1986) Isotopic studies of nitrogen pollution in the hydrosphere and atmosphere: a review. Chem. Geol. 59, 87-102.

Hinkle, S. R. (1997) Quality of shallow groundwater in alluvial aquifers of the Willamette Basin, Oregon, 1993-95: U.S.G.S. Water Resources Investigation Report 97-4082-B, $48 \mathrm{pp}$.

Holak, W. (1980) Determination of arsenic by cathodic stripping voltammetry with a hanging mercury electrode. Anal. Chem. 52, 2189-2192.

Itai, T. and Kusakabe, M. (2004). Some practical aspects of an online chromium reduction method for $\mathrm{D} / \mathrm{H}$ analysis of natural waters using a conventional IRMS. Geochem. J. 38, 435440.

Jacks, G., Bhattacharya, P., Chaudhary, V. and Singh, K. P. (2005) Controls on the genesis of some high fluoride groundwaters in India. Appl. Geochem. 20, 221-228.

Jacobs, L. W., Syers, J. K. and Kenney, D. R. (1970) Arsenic sorption by soils. Soil Sci. Soc. Am. Proc. 34, 750-754.

JICA and Pakistan EPA (2000) Investigation of Air and Water Quality in Lahore, Rawalpindi and Islamabad. Hagler Bailly Pakistan, $224 \mathrm{pp}$.

Laura, V., Neus, O., Albert, S. and Angels, C. (2004) Fertilizer characterization: Isotopic data (N, S, O, C and Sr). Environ. Sci. Tech. 38, 3254-3262.

Lepkowski, K. W. (1998) Arsenic crisis in Bangladesh. Chem. Eng. News 76, 27-30.

Li, X., Masuda, H., Koba, K. and Zehng, H. (2007) Nitrogen isotope study on nitrate-contaminated groundwater in the Sichuan Basin, China. Water, Air, Soil Pollut. 178, 145-156.

Lindberg, J., Sterneland, J., Johansson, P. O. and Gustafsson, J. P. (1997) Spodic material for in-situ treatment of arsenic in groundwater. Ground Water Monit. Remidiat. 17, 125130 .

Mahmood, S. N., Naeem, S., Siddiqui, I. and Khan, F. A. (1998) Studies on Physico-chemical nature of groundwater of Korangi/Landhi (Karachi). J. Chem. Soc. Pakistan 19, C4248.

Manning, B. A. and Goldberg, S. (1997) Adsorption and stability of arsenic (III) at the clay mineral-water interface. Environ. Sci. Tech. 31, 2005-2011.

Matisoff, G., Khourey, C. J., Hall, J. F., Varnes, A. W. and Strain, W. (1982) The nature and source of arsenic in Northeastern Ohio groundwater. Ground Water 20, 446-455.

McArthur, J. M., Ravenscroft, P., Safiullah, S. and Thirlwall, M. F. (2001) Arsenic in groundwater: testing pollution mechanisms for aquifers in Bangladesh. Water Res. 37, 109117.

McLaughlin, M. J., Tiller, K. G., Naidu, R. and Stevens, D. P. (1996) Review: the behavior and environmental impact of contaminants in fertilizers. Aus. J. Soil. Res. 34, 1-54.

Nakai, N. and Jensen, M. L. (1967) Source of atmospheric sulfur compounds. Geochem. J. 1, 199-210.

Nanyaro, J. T., Aswathanarayana, U., Mungere, J. S. and Lahermo, P. (1984) A geochemical model for the abnormal fluoride concentrations in waters in parts of northern Tanzania. J. Afr. Earth Sci. 2, 129-140.

Nickson, R. T., McArthur, J. M., Burgess, W., Ahmed, M., Ravenscroft, P. and Rahman, M. (1998) Arsenic poisoning of groundwater in Bangladesh. Nature 395, 338.

Nickson, R. T., McArthur, J. M., Sherestha, B., Kyaw-Myint, T. O. and Lowry, D. (2005) Arsenic and other drinking water quality issues, Muzaffargarh district, Pakistan. Appl. Geochem. 20, 55-68.

Nimick, D. A. (1998) Arsenic hydrochemistry in an irrigated river valley-a re-evaluation. Ground Water 36, 743-753.

Ohizumi, T., Fukuzaki, N. and Kusakabe, M. (1997) Sulfur isotopic view on the sources of sulfur in atmospheric fallout along the coast of the Sea of Japan. Atmos. Environ. 31, 1339-1348. 
Parkhurst, D. L. (1995) PHREEQC -A computer program for speciation, reaction path, advective-transport, and inverse geochemical calculations. U.S.G.S. Water Resources Inventory, 95-4227.

Pickering, W. F. (1985) The mobility of soluble fluoride in soils. Environ. Pollut. 9, 281-308.

Pierce, M. L. and Moore, C. B. (1982) Adsorption of arsenite and arsenate on amorphous iron oxyhydroxide. Water Res. 16, 1247-1253.

Punjab EPD (1998-99) Study on Ambient Air Quality in Lahore and Rawalpindi, $178 \mathrm{pp}$.

Rabano, E. S., Castillo, N. T., Torre, K. T. and Solomon, P. A. (1989) Speciation of arsenic in ambient aerosols collected in Los Angeles. J. Air Pollt. 39, 76-80.

Ramamohana Rao, N. V., Rao, N., Surya Prakash Rao, K. and Schuiling, R. D. (1993) Fluorine distribution in waters of Nalgonda district, Andhra Pradesh, India. Environ. Geol. 21, 84-89.

Robertson, F. N. (1989) Arsenic in groundwater under oxidizing conditions, south-west United States. Environ. Geochem. Health 11, 1247-1253.

Sarma, D. R. R. and Rao, S. L. N. (1997) Fluoride concentrations in groundwaters of Visakhapatnam, India. J. Environ. Cont. Tox. 58, 241-247.

Schreiber, M. E., Simo, J. A. and Freiberg, P. G. (2000) Stratigraphic and geochemical controls on naturally occurring arsenic in groundwater, eastern Wisconsin, USA. Hydro. J. 8, 161-176.

Shimizu, K., Itai, T. and Kusakabe, M. (2006) Ion chromatographic determination of fluorine and chlorine in silicate rocks following alkaline fusion. The J. Geostand. Geoanal. (in press).

Sigma, D. M., Altabet, M. A., Michener, R., McCorkle, D. C., Fry, B. and Holmes, R. M. (1997) Natural abundance level measurement of the nitrogen isotopic composition of oceanic nitrate: an adaptation of the ammonia diffusion method. Mar. Chem. 57, 227-242.

Skjelkvale, B. L. (1994) Factors influencing fluoride in Norwegian Lakes. Water Air Soil Pollut. 77, 151-167.

Smedley, P. L., Nicolli, H. B., Macdonald, D. M. J., Barros, A. J. and Tullio, J. O. (2002) Hydrogeochemistry of arsenic and other inorganic constituents in groundwaters from La Pampa, Argentina. Appl. Geochem. 17, 259-284.

Szogi, A. A., Hunt, P. G., Sadler, E. J. and Evans, D. E. (2004) Characterization of oxidation-reduction processes in constructed wetlands for swine wastewater treatment. Appl. Eng. Agr. 20, 189-200.
Tasneem, M. A. (1999) Impact of agricultural and industrial activities on groundwater quality in Kasur area. The $\mathrm{Nu}$ cleus, Quarterly J. Pakistan. Atomic Ene. Comm. 36.

Tian, D. F., Ma, H., Feng, Z., Xia, Y., Le, X. C., Ni, Z., Allen, J., Collins, B., Schreinemachers, D. and Mumford, J. L. (2001) Analyses of micronuclei in exfoliated epithelial cells from individuals chronically exposed to arsenic via drinking water in Inner Mongolia, China. J. Tox. Environ. Health, Part A 64, 473-484.

Varsanyi, I., Fodre, Z. and Bartha, A. (1991) Arsenic in drinking water and mortality in the southern Great Plain, Hungary. Environ. Geochem. Health. 13, 14-22.

Waldman, J. M., Lioy, P. J., Zelenka, M., Jing, L., Lin, Y. N., He, Q. C., Qian, Z. M., Chapman, R. and Wilson, W. E. (1991) Winter time measurements of aerosol acidity and trace elements in Wuhan, a city in central China. Atmos. Environ. 25B, 113-120.

Wang, X. C., Kawahara, K. and Guo, X. J. (1999) Fluoride contamination of groundwater and its impact on human health in Inner Mongolia area. Aqua 48, 146-153.

WAPDA-EUAD (Water and Power Development Authority, Environment and Urban Affairs Division) (1989) Booklet on Hydrogeological Map of Pakistan, 1:2,000,000 Scale. Lahore Government of Pakistan, WAPDA-EUAD.

Welch, A. H., Westjohn, D. B., Heisel, D. R. and Wandy, R. B. (2000) Arsenic in groundwater of the United States: Occurrence and geochemistry. Ground Water 38, 589-604.

WHO (World Health Organization) (1993) Guideline values for arsenic. WHO Technical Report Series 776, Chapter 5, 8 pp.

WHO (World Health Organization) (1994) Fluorides and oral health. WHO Technical Report Series 846, Chapter 3, 5 pp.

Widory, D., Kloppmann, W., Chery, L., Bonnin, J., Rochdi, H. and Guinamant, J. (2004) Nitrate in groundwater: an isotopic multi tracer approach. J. Cont. Hydr. 72, 165-188.

Woolson, E. A., Axley, J. H. and Kearney, P. C. (1971) The chemistry and phytotoxicity of arsenic in soils: I. contaminated field soils. Soil Sci. Soc. Amer. Proc. 35, 938-943.

Yanagisawa, F. and Sakai, H. (1983) Preparation of $\mathrm{SO}_{2}$ for sulfur isotope ratio measurements by thermal decomposition of $\mathrm{BaSO}_{4}-\mathrm{V}_{2} \mathrm{O}_{5}-\mathrm{SiO}_{2}$ mixtures. Anal. Chem. 55, 985987.

\section{APPENDIX}

(see p. 231-234). 


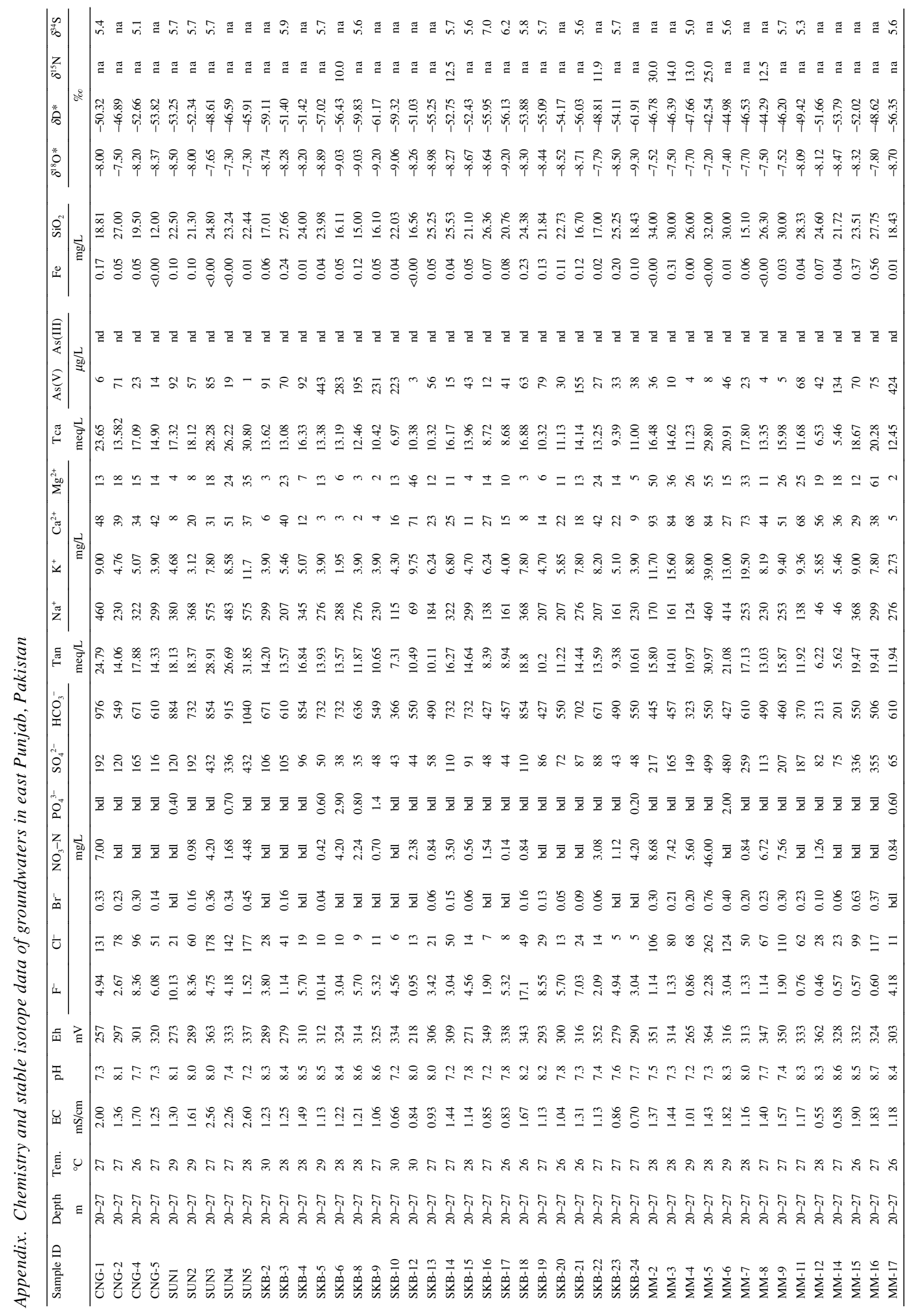




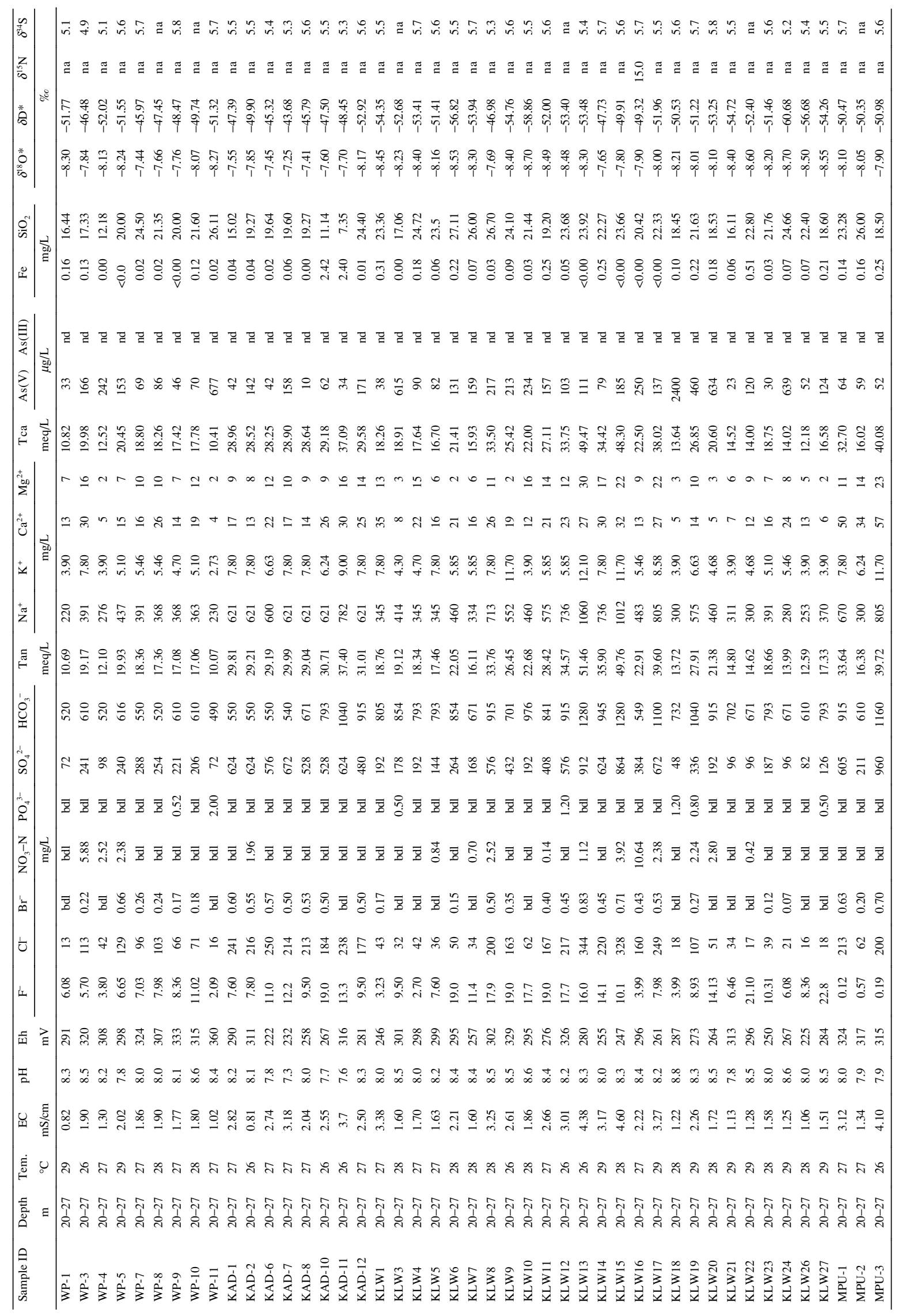




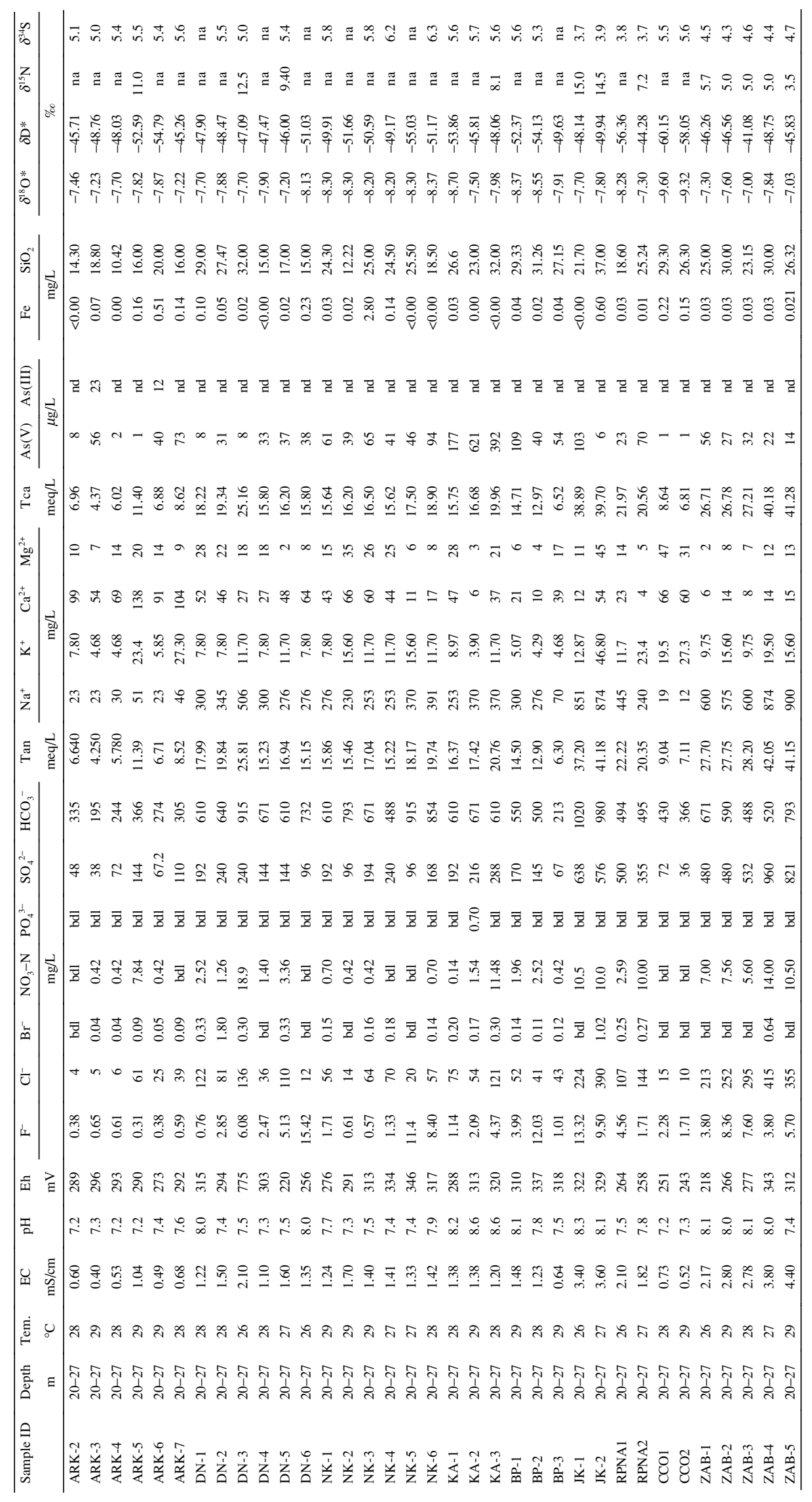

High arsenic and fluoride contaminated groundwater from East Punjab, Pakistan 233 


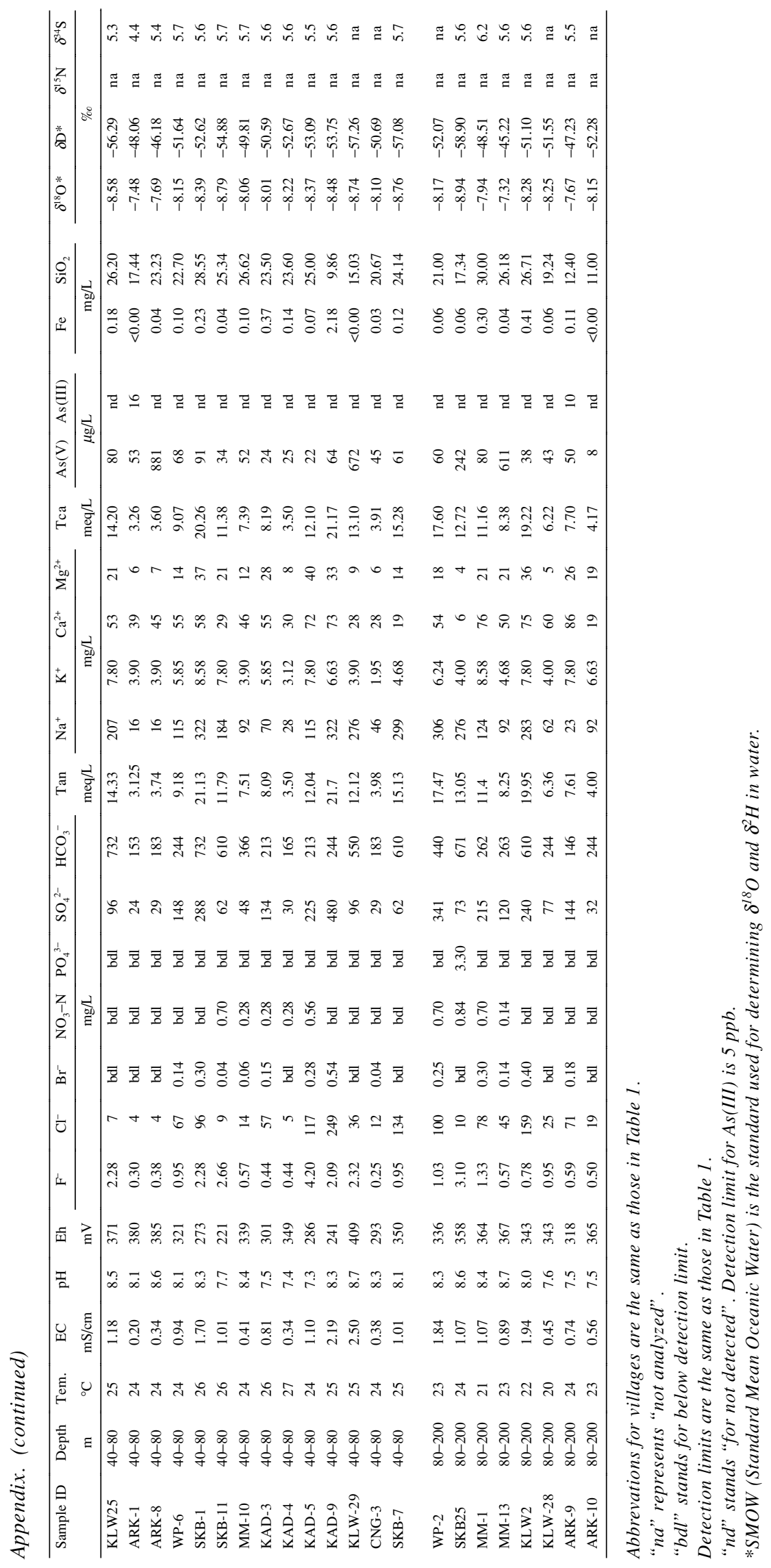

